\title{
The Human Rights Dynamics of Abortion Law Reform
}

\author{
Bernard Dickens \& Rebecca Cook
}

Version Publisher's Version

Citation Bernard Dickens \& R. J. Cook, "Human Rights Dynamics of Abortion (published version) Law Reform" (2003) 25 Human Rights Quarterly 1-59.

Copyright / License Copyright (C) 2003 The Johns Hopkins University Press. This article was first published in Human Rights Quarterly 25:1(2003), 1. Reprinted with permission by Johns Hopkins University Press.

How to cite TSpace items

Always cite the published version, so the author(s) will receive recognition through services that track citation counts, e.g. Scopus. If you need to cite the page number of the author manuscript from TSpace because you cannot access the published version, then cite the TSpace version in addition to the published version using the permanent URI (handle) found on the record page.

This article was made openly accessible by $U$ of $T$ Faculty. Please tell us how this access benefits you. Your story matters. 


\title{
Human Rights Dynamics of Abortion Law Reform
}

\author{
Rebecca J. Cook* \\ Bernard M. Dickens**
}

Table of Contents

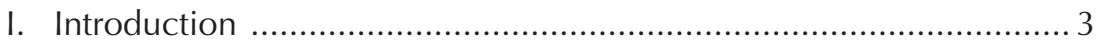

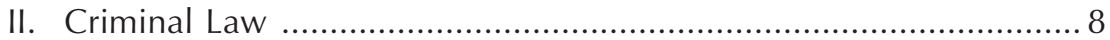

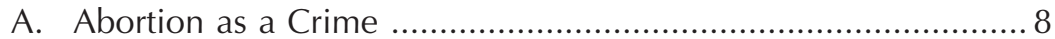

B. Evidence of Crime ...................................................................... 9

C. The Human Rights Violation of Forced Pregnancy .................. 10

* Rebecca J. Cook received her A.B. from Barnard, her M.A. from Tufts, and her M.P.A. from Harvard. She received a J.D. from Georgetown, an LL.M. from Columbia, and an J.S.D. from Columbia. She is a Professor in the Faculty of Law, the Faculty of Medicine and the Joint Centre for Bioethics at the University of Toronto; Co-Director, International Programme on Reproductive and Sexual Health Law, University of Toronto. She is ethical and legal issues co-editor of the International Journal of Gynecology and Obstetrics, and serves on the editorial advisory boards of Human Rights Quarterly and Reproductive Health Matters. Her publications include over one hundred and fifty books, articles, and reports in the areas of international human rights, the law relating to women's health and feminist ethics. She is the recipient of the Certificate of Recognition for Outstanding Contribution to Women's Health by the International Federation of Gynecologists and Obstetricians, the Ludwik and Estelle Jus Memorial Human Rights Prize, and is a Fellow of the Royal Society of Canada.

** Bernard M. Dickens is the Dr. William M. Scholl Professor of Health Law and Policy at the Faculty of Law, cross-appointed to the Faculty of Medicine and Joint Centre for Bioethics. After completing a Ph.D. degree in Law at the University of London and coming to the University of Toronto in 1974, he earned a higher doctorate (LL.D. degree) in Medical Jurisprudence. He has over 300 publications primarily in medical law and bioethics, and many international collaborations. In 1990-1991 he was president of the American Society of Law, Medicine and Ethics, and is currently a vice-president of the World Association for Medical Law. He has worked on several World Health Organization projects, particularly on human experimentation and organ transplantation. Professor Dickens is legal articles editor of The Journal of Law, Medicine and Ethics, and on editorial boards of several medical law journals. His major current research collaboration is with Professor Rebecca Cook and Dr. Mahmoud Fathalla to produce a book (Oxford University Press) on reproductive and sexual health law. 


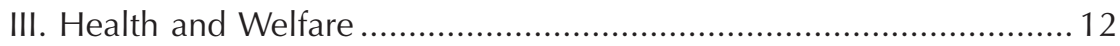

A. The Comprehensive Reproductive Health Framework ............. 12

B. Legal Reproductive Health Care ............................................. 14

C. Safe and Accessible Abortion Services .................................... 16

D. Unsafe Abortion and Maternal Mortality ............................... 17

E. The Public Health Setting ...................................................... 19

IV. Human Rights, Human Dignity, and Social Justice ........................ 21

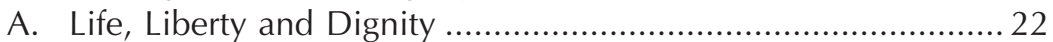

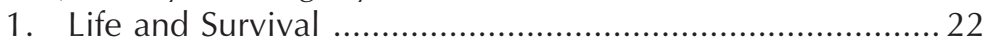

a. Legal Protection of Life from Conception or Birth ....... 22

b. Positive Obligations to Protect Life ............................... 28

2. Liberty and Security ......................................................... 29

3. Human Dignity and Freedom from Inhuman and

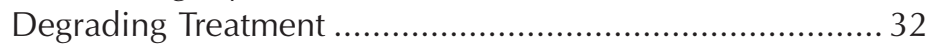

B. Non-discrimination and Due Respect for Difference ............... 34

1. Sexual Non-Discrimination ................................................ 35

a. CEDAW General Recommendation 24: Women

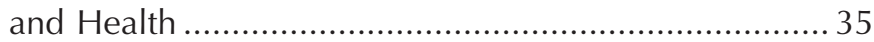

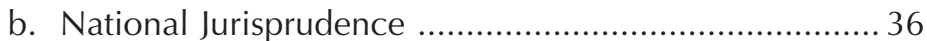

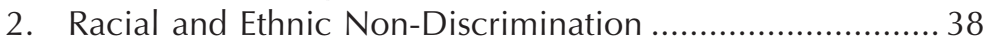

3. Age Non-Discrimination ............................................ 41

4. Non-Discrimination on Grounds of Health

Status/Disability .............................................................. 42

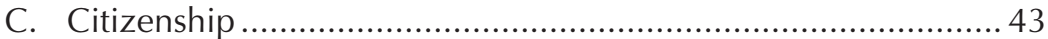

1. Women as Equal Citizens ................................................ 43

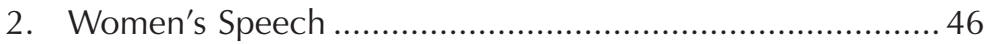

3. Women's Choice: Third Party

Authorization Requirements ............................................. 49

4. Conscience and Professional Duty ................................... 50

V. A Way Forward: Human Rights Needs Assessment ........................ 53

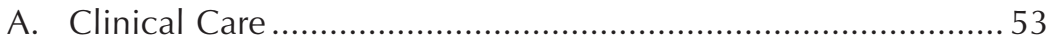

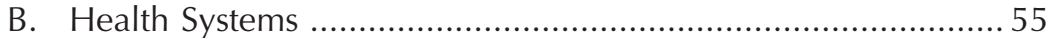

C. Social, Economic and Legal Conditions ................................ 58

\begin{abstract}
The legal approach to abortion is evolving from criminal prohibition towards accommodation as a life-preserving and health-preserving option, particularly in light of data on maternal mortality and morbidity. Modern momentum for liberalization comes from international adoption of the concept of reproductive health, and wider recognition that the resort to safe and dignified healthcare is a major human right. Respect for women's reproductive self-determination legitimizes abortion as a choice when family planning services have failed, been inaccessible, or been denied by
\end{abstract}


rape. Recognition of women's rights of equal citizenship with men requires that their choices for self-determination be legally respected, not criminalized.

\section{INTRODUCTION}

The purpose of this article is to address the modern human rights dynamics of abortion law reform. The inspiration for reform varies among countries, and often depends upon contextual factors peculiar to individual countries. In some, abortion law reform is a function of respect for women's autonomy and self-determination, while in others it is a response to demonstrated public health dysfunctions of restrictive laws and health services. In yet other countries, reform is addressed at the level of social justice and equality, or at the political level of rights of citizenship and democracy. Mounting resistance to colonization and dictatorships, whether military, political, or religious, is leading to increasingly widespread resistance to colonization and dictatorship over women's bodies and reproductive choices. Respect is growing for women's claims to reproductive rights as a necessary part of citizenship.

The dynamics of reform have been aided, and occasionally triggered, by richer varieties of pragmatic research in the social and public health sciences, and by the growing influence of feminist theories or explanations, about law, social organization, and politics. The statistical and related data have interacted with feminist explanations of the gendered nature of restrictive abortion laws and practices, to reveal the devastating impact on women's lives of unsafe and unplanned pregnancy, and denial of access to legal abortion services. In many countries of the world, women's alternative to unsafe abortion is not safe pregnancy and childbirth, but predictable complications during pregnancy resulting in maternal death or disability, precluding or compromising women's ability to care for their dependent children, and to live as full citizens.

The historical fashioning of restrictive abortion laws in Western countries, and their transmission and retention in other regions through patterns of European colonization, have resulted in an imbalance in their impact between economically developed and still developing countries. The World Health Organization (WHO) estimates that worldwide, approximately 20 million unsafe abortions occur every year, resulting in 78,000 deaths. Of these, an estimated 77,500 occur in developing countries. ${ }^{1}$ While there has been a definite liberalization of abortion laws since 1950 in the developed

1. World Health Organization (WhO), Unsafe Abortion: Global and Regional Estimates of Incidence of and Mortality Due to Unsafe Abortion with a Listing of Avallable Country Data 8 (1998). 
world, this has not been the case in the developing world. ${ }^{2}$ Unsafe abortion is particularly common in many countries with restrictive abortion laws, such as in Latin America. ${ }^{3}$ It is estimated that every year approximately four million Latin American women undergo unsafe abortion, most of which are illegal. ${ }^{4}$ In particular countries, hospital-based studies have specified the health impact of unsafe abortion, showing how urgent demands for treatment for abortion complications compromise routine maternity care where resources are scarce. ${ }^{5}$

The International Inter-agency Safe Motherhood Initiative, ${ }^{6}$ beginning in the late 1980s and reinforced in the late 1990s, ${ }^{7}$ has triggered growing international sensitivity to the burden in many countries, and to the universal injustice, of preventable pregnancy-related death, scientifically referred to as maternal mortality. The concept of reproductive health has emerged in relation to this Initiative, as a specific application of the concept of health itself. Health is described in the WHO Constitution as "a state of ... physical, mental and social well-being." The concept of reproductive health has been internationally endorsed and legitimized through UN conferences, particularly the 1994 International Conference on Population and Development, held in Cairo, ${ }^{8}$ and the 1995 Fourth World Conference on Women, held in Beijing. ${ }^{9}$ This reproductive health concept was strengthened in subsequent five-year review conferences in $1999^{10}$ and $2000^{11}$ respectively. Both original and review conferences recognized the indi-

2. The Allan Guttmacher Institute, Sharing Responsibility: Women Society \& Abortion Worldwide 23 (1999).

3. John M. Paxman et al., The Clandestine Epidemic: The Practice of Unsafe Abortion in Latin America, 24 Stud. Fam. Plan. 205 (1994).

4. The Alan Guttmacher Institute, Clandestine Abortion: A Latin American Reality (1994) at 53, supra note 2 .

5. See, e.g., Susan Checa \& Martha I. Rosenberg, Aborto Hospitalizado: Un Problema de Salud Publica, Una Cuestion de Derechos Reproductiva (Hospitalized Abortion: A Public Health Problem, A Question of Reproductive Rights) (1996).

6. These agencies are of the World Health Organization, UNICEF, UNFPA, Population Council, International Planned Parenthood Federation, and Family Care International.

7. Anne Starrs, The Safe Motherhood Action Agenda: Priorities for the Next Decade: Report on the Safe Motherhood Technical Consultation 18-23 (1998).

8. Report of the International Conference on Population and Development, U.N. Doc. A/ Conf.171/13 (1994) at II 7.2 [hereinafter the Cairo Programme].

9. Fourth World Conference on Women: Action for Equality, Development, and Peace, Beijing Declaration and Platform for Action, U.N. Doc. A/CONF. 177/20 (1995) at II 94 [hereinafter the Beijing Platform].

10. Report of the Ad Hoc Committee of the Whole of the Twenty-first Special Session of the General Assembly-Overall review and appraisal of the implementation of the Programme of Action of the International Conference on Population and Development, U.N. Doc. A/S-21/5/Add.1 (1999) [hereinafter Cairo+5].

11. Report of the Ad Hoc Committee of the Whole of the Twenty-third Special Session of the General Assembly-Further Actions and Initiatives to Implement the Beijing Declaration and the Platform for Action, U.N. Doc. A/S-23/10/Rev.1 (2000) [hereinafter Beijing+5]. 
vidual misfortune of unplanned pregnancy, and the aggravation of risks due to women's obstructed access to safe reproductive health care services, and women's common resort to abortions that are unsafe because of restrictions on procedures that can be undertaken in lawful, safe conditions.

Through the 1995 Beijing Conference and resulting Platform, 187 UN member states have gone beyond recognition of the individual risks of unsafe abortion, and adopted the commitment to "deal with the health impact of unsafe abortion as a major public health concern."12 This article explains the history of abortion regulation through criminal law, and how such law has proven dysfunctional to the protection of reproductive health at the levels of both clinical and public health services. It addresses the significance of the concept of reproductive health, and how this fits into the wider framework of human rights to promotion of health and other interests that are the concern of the transcending human rights movement. The dynamic compelling consideration of abortion law reform is that criminalization of a practice that each year worldwide an estimated 20 million women seek in unsafe conditions denies their right to reproductive health in particular, and to respect for their human rights in general. The focus of concern arises, however, not just from the cumulative impact of 20 million cases, but from the risk posed to each individual woman.

Abortion laws have evolved through courts and human rights tribunals around the world interpreting human rights to recognize, and sometimes to deny, women's rights of access to abortion services and information. Courts and human rights tribunals among themselves often reflect different views on the legitimate use of law. One view is that law is an acceptable instrument to express and enforce the moral prohibition of abortion, by including criminal sanctions. Another view is that the demonstrable consequences of attempting to restrict abortion by the application of criminal sanctions are detrimental to women. They often compel continuation of pregnancies that cost women their lives or health, or lead to unskilled interventions in pregnancy that bear the same costs. Criminal sanctions are therefore rejected, on grounds of their dysfunctions.

Yet another view places abortion within a spectrum of services to which women should have safe access as a matter of human rights and of social justice in recognizing women as competent and conscientious decisionmakers in their own lives. ${ }^{13}$ Reproductive rights require that attention and respect be afforded the decisions of the approximately 20 million women each year who feel the need to resort to abortion even in unsafe circumstances.

12. Beijing Platform, supra note 9, II 8.25.

13. Rebecca J. Cook, Bernard M. Dickens \& Laura E. Bliss, International Developments in Abortion Law from 1988 to 1998, 89 Aм. J. Pub. Health 579 (1999). 
Within the context of human rights, there are additional new ways beyond the framework of reproductive health of conceptualizing the problem of abortion. For example, the Committee on the Elimination of Discrimination against Women (CEDAW) ${ }^{14}$ characterizes the refusal of medical procedures that only women require, such as abortion, as sex discrimination..$^{15}$ The growth of modern human rights law is founded on the claim that states are not sovereign to exercise unfettered intervention in their citizens' lives, but are accountable to transcending principles of human dignity that require their respect for individuals' rights. Accordingly, this assessment of evolving human rights dimensions of abortion laws and policies will consider human rights related to clinical abortion services, governmental responsibility for delivery and non-delivery of services, including preventive family planning services, and such related issues as the right to receive and impart information with regard to abortion.

Modern evolution of abortion law associates enforcement of repressive legislation with non-democratic governments and authoritarian religious institutions that are scornful of egalitarian "rights talk." They are fearful that women's achievement of their reproductive choices would subvert governmental and institutional pro-natalist policies, and are indifferent to the harmful impact of punitive measures on the lives of women and families. Legal approaches concerned to minimize harms to health from unplanned pregnancies accommodate abortion, but recognize how resourceful programs of sex education and family planning can reduce its incidence. Countries such as South Africa that have newly come to democracy based on an enfranchised electorate, where those who employ political power are accountable to the electorate, are taking initiatives to situate their abortion legislation within frameworks that implement principles of respect for women's human rights that are internationally recognized.

There are, of course, some modern democracies whose abortion laws remain expressed primarily in restrictive, criminally focused terms. Movement towards legal reform is not universal, and remains resisted within some democratic political establishments, particularly when leading members of their ruling elites and judiciaries are in thrall to religious authorities that have no commitment to democratic reform of conservative laws. How-

14. The Convention on the Elimination of All Forms of Discrimination Against Women established the Committee as the treaty monitoring body to monitor state compliance with the treaty. The Convention on the Elimination of All Forms of Discrimination Against Women, adopted 18 Dec. 1979, G.A. Res. 34/180, U.N. GAOR 34th Sess., Supp. No. 44 at 193, U.N. Doc. A/34/36 (1980) (entered into force 3 Sept. 1981), reprinted in 19 I.L.M. 33 (1980) [hereinafter the Women's Convention].

15. Committee on the Elimination of Racial Discrimination, (CERD) Gen. Rec. 24: Women and Health, III 11, 14, UN GAOR, 1999, UN Doc. A/54/38/Rev 1, 3-7. 
ever, experience over the last three decades shows an emerging trend of liberalization, although over the most recent decade this has been at a slower rate, and in some countries the trend is facing a backlash in restrictive legislation and court decisions, ${ }^{16}$ and funding policies.

The backlash in funding policies is exemplified by US foreign aid policy conducted through the United States Agency for International Development. The policy restricts overseas non-governmental organizations that receive US aid from using their own private money to provide abortion services, to advocate for liberalizing change in their domestic law on abortion, or even to offer full and accurate medical information about legal abortion services to their patients. This policy, known as the Global Gag Rule, initially instituted under the Reagan administration, ${ }^{17}$ and reinstated by President George W. Bush in January 2001, ${ }^{18}$ undermines the ability of recipients to exercise free speech ${ }^{19}$ and to participate in their own civil societies and democracies.

Legislatures and judiciaries respectful of women's views, including those that hear women's voices from within their own memberships, are progressively molding legislation and its interpretation sympathetically to women's interests in health, and in observance of human rights. ${ }^{20}$ As women become equal citizens with men in their societies, it is anticipated that abortion concerns will evolve from placement within criminal or penal codes, to placement within health or public health legislation, and eventually to submergence within laws serving goals of human rights, social justice, and the individual dignity of control over one's own body.

16. Rebecca J. Cook \& Bernard M. Dickens, A Decade of International Change in Abortion Law: 1967-1977, 68 Aм. J. Pub. Health, 637-44 (1978); Rebecca J. Cook \& Bernard M. Dickens, International Developments in Abortion Law: 1977-88, 78 Am. J. PuB. Health 1305-11 (1988); Cook, Dickens \& Bliss, International Developments in Abortion Law from 1988 to 1998 , supra note 13.

17. Standard Provisions for US Grantees and US Subgrantees, reprinted in US Agency for International DeVelopment, 13 AID Handbook, 4C-45-50 (1985). This policy was announced by the Reagan administration at the 1984 Conference on Population and Development in Mexico City, and thus became known as the Mexico City Policy.

18. See 22 Jan. 2001 Presidential Memorandum and its implementing Memorandum, of 28 Mar. 2001-Restoration of the Mexico City Policy, 66 Fed. Reg. 61, at 17303 (29 Mar. 2001).

19. Center for Reproductive Law and Policy v. Bush, No. CIV.A.01-6168, 2002 WL 31045183 (D.NY.Sept. 13, 2002). U.S. Court of Appeals for the Second Circuit did not find this argument convincing.

20. European Parliament (Committee on Women's rights and Equal Opportunities), Report on Sexual and Reproductive Health and Rights (6 June 2002). 


\section{CRIMINAL LAW}

\section{A. Abortion as a Crime}

Historical systems of Western customary law, such as the Anglo-Saxon Common law, derived many offenses from religious concepts of sin, and treated deliberate termination of pregnancy as an offense. However, Common law considered pregnancy to begin only when it was first evidenced, through 'quickening'. ${ }^{21}$ Evidence of quickening became available at a time that coincides in general with the end of the first trimester and beginning of the second trimester of pregnancy, that is at about the twelfth or thirteenth week of gestation. ${ }^{22}$ Accordingly, absence of a single menstrual period or two consecutive periods was not legal evidence of pregnancy notwithstanding any medical practice to measure the length of gestation from the last menstrual period.

In the customary or Common law tradition, practices are legally permissible unless they violate a prohibitive provision of the law declared by a court or enacted by a legislature. Accordingly, abortion is permissible unless expressly prohibited. When English law changed in 1803 with legislation intended to protect women from "procuring a miscarriage" by seeking or self-administering any potentially harmful procedure, it made abortion both before and after quickening a crime, but only when undertaken "unlawfully." Following statutory amendments in 1828 and 1837, the offense was incorporated into the Offences Against the Person Act, 1861, section 58 of which remains the foundation of the abortion prohibition in many jurisdictions of the common law world and beyond. The section provides that:

Every woman, being with child, who, with intent to procure her own miscarriage, shall unlawfully administer to herself any poison or other noxious thing, or shall unlawfully use any instrument or other means whatsoever with the like intent and whosoever, with intent to procure the miscarriage of any woman whether she be or be not with child, shall unlawfully administer to her or cause to be taken by her any poison or other noxious thing, or shall unlawfully use any instrument or other means whatsoever with the like intent, shall be guilty of felony.

21. Bernard M. Dickens, Abortion and the Law 20-28 (1966).

22. In 1973 the United States Supreme Court, in Roe v. Wade, 410 U.S. 113 (1973), looked to the law that existed at the time the United States Constitution was drafted at the end of the eighteenth century, and held that later legislation restricting abortion before the second trimester, that is before the historical time of quickening, violated women's constitutional rights, and that prohibition of second and third trimester abortion was subject to judicial scrutiny. 
Two developments in the understanding of this law warrant special attention. First, in 1869, the Roman Catholic Church redefined the mortal sin of abortion in its tradition to apply not simply from quickening, as before, but from conception. This reinforced the secular criminal law with religious support, and made defense of the criminal law a matter of concern to religious interests and institutions. Second, in 1938 in the widely influential Bourne case, ${ }^{23}$ it was judicially determined that, under section 58 of the 1861 Act, there remained a category of lawful abortion. In Bourne, the judge directed the jury that a person would not act "unlawfully" for terminating a pregnancy in order to preserve a woman's life or her physical or mental health. The jury acquitted the defendant physician for terminating the pregnancy of a 15-year-old rape victim he feared would become "a mental wreck" by continuation of pregnancy and childbirth.

In systems of European codified law following the system of the Code Napoléon, where all rights must be contained within the framework of the Code, abortion has similarly tended to be addressed through penal or criminal provisions that reflect a religious sense of sin. Such codes tended not to address such issues as access to health services, and not to define rights of medical practice. Colonizing European countries in which the Roman Catholic Church was influential, such as France, Spain, and Portugal, have left a legacy of criminal prohibition of abortion in the laws of the countries they once dominated, such as in Africa and in Latin America. Thus, the modern history of abortion law has emphasized the criminal nature of the practice and the punishment of those who request and perform it. Criminal provisions have been invoked to support spiritual values inherent in unborn life, rather than to give explicit recognition to women's countervailing rights to protect their own lives or health endangered by continuation of pregnancy.

\section{B. Evidence of Crime}

Human reproduction is often viewed through a gendered lens that blames women both for a couple's infertility and for unplanned pregnancy. The punitive approach that mandates continuation of pregnancy a woman has voluntarily risked through sexual intercourse has persisted, despite its common cruelty and ignorance of the many circumstances in which women's capacity to resist spousal or other intercourse is so compromised as not to constitute their genuine choice. Nevertheless, many criminal laws

23. R. v. Bourne, 1 King's Bench 687 (Central Criminal Court, London, 1938). 
that hold to this view recognize that rape, to which incest is often allied, is an exception that justifies abortion.

The gendered view remains, however, that womankind is disposed to seduction and deception of men, and that an allegation of rape is easily made and difficult to defend. Many claims remain legally inadmissible where courts deny that forced intercourse by a husband can in law constitute rape. Where rape can be claimed, demanding evidentiary standards have arisen to determine whether the admitted intercourse was rape, rather than sinful fornication or adultery. Standards of criminal evidence of rape have historically required the subject's contemporaneous complaint and signs of violent sexual penetration, forceful resistance, and even ejaculation. The justification of prompt invasive forensic testing of women alleging rape, which many have described as the second rape, ${ }^{24}$ has been that the exception that justifies abortion must be applied only narrowly and strictly. The proportion of women who falsely allege that their pregnancy is due to rape is contentious, and depends in part on the credibility that societies attach to women's statements. Studies have identified that many women do not complain of rape, out of a sense of shame or future disadvantage to marriage prospects, or, for instance, fear of further violence. Similarly, women are often aware of the futility of contemporaneous complaint, such as when rape is perpetrated by men in positions of power or authority, such as police officers, jail guards, and priests. ${ }^{25}$ They disclose the rape only later, upon evidence of pregnancy. As a matter of justice, however, no complaint justifies rejection for weakness of legally admissible evidence; that is, even a willfully deceptive complainant does not deserve corporal punishment by continued pregnancy and childbirth. A system of criminal law would fulfill its purposes by allowing prompt abortion on a woman's complaint, and applying its regular sanctions for deliberate falsehood. Sanctions include punishment for the offenses of knowingly making false reports to police or other officers, and of perjury in making false statements on oath. Offenses of making false claims in requests for abortion are analogous to obtaining an advantage by fraud or false pretenses.

\section{The Human Rights Violation of Forced Pregnancy}

Criminal and penal law systems are becoming progressively enlightened by developments in human rights law. One expression is the recognition of

24. Kathleen Kelly et al., Insult to Injury? The Medical Investigation of Rape in England and Wales, 20 (4) J. Soc. Welfare \& Fam. L. 409, 410 (1998).

25. See Susan Estrich, Real Rape (1987) quoted in Lee Madigan \& Nancy C. Gamble, The Second Rape: Society's Continued Betrayal of the Victim 3 (1991). 
domestic violence, and that women can suffer rape by nonconsensual intercourse committed by their husbands. Another is the admission of victim impact statements at criminal sentencing, when the trauma a rape victim suffered, including pregnancy and its termination, is relevant to a convicted offender's sentence. A further human rights development is in the human rights requirement of victim rehabilitation, by which legal systems must make efforts to restore victims of crimes and human rights violations to the status they would have enjoyed but for the violation they have been forced to endure. This is the principle according to which many prohibitive criminal abortion laws recognize rape as an exception. It is also the principle that recognizes the human rights violation constituted by criminal abortion laws that refuse or fail to accommodate a rape exception, and perpetuate women's victimization by compelling involuntary continuation of pregnancy. The Beijing Platform declares that:

The human rights of women include their right to have control over and decide freely and responsibly on matters related to their sexuality, including sexual and reproductive health, free of coercion, discrimination and violence..$^{26}$

It is accordingly a human rights infringement when women who have suffered the violation of rape are compelled to endure pregnancy against their will by the coercion of criminal sanctions. The Platform further condemns "torture . . . sexual slavery, rape, sexual abuse and forced pregnancy." ${ }^{27}$ Forced pregnancy describes both forced initiation of pregnancy, and forced continuation of pregnancy. The Treaty of Rome constituting the jurisdiction of the International Criminal Court similarly recognizes forced pregnancy as a crime against humanity. ${ }^{28}$ This was in reaction to preceding evidence, presented before tribunals addressing humanitarian outrages in conflicts in the former Yugoslavia and Rwanda, of systematic rape as part of "ethnic cleansing," when women pregnant by rape were denied abortion due to religious influence. Countries with criminal laws that do not permit abortion for rape recognized their vulnerability to condemnation for perpetrating forced pregnancy, and joined the Treaty only upon the acceptance of Treaty language providing that their legislation does not violate the Treaty. Nevertheless, human rights treaty monitoring bodies have identified the inconsistency between human rights principles and criminal abortion laws that have no explicit exception that allows lawful abortion on complaints of rape.

26. Beijing Platform, supra note 9, II 96.

27. Beijing Platform, supra note 9, II 135.

28. Rome Statute on the International Criminal Court, U.N. Doc. A/Conf. 183/9 (1998), reprinted in 37 I.L.M. 999 (1998), art. 7(1)(g). 
Recognition of forced pregnancy, however initiated, exposes the coercion women suffer to continue pregnancies against their will, by criminal laws and other means, as a human rights violation. ${ }^{29}$ This is analogous to rape and sexual abuse. The Chief Justice of Canada, in a majority judgment holding Canada's restrictive criminal abortion law unconstitutional and inoperative, observed in 1988 that:

Forcing a woman, by threat of criminal sanction, to carry a foetus to term unless she meets certain criteria unrelated to her own priorities and aspirations, is a profound interference with a woman's body and thus a violation of security of the person. ${ }^{30}$

This re-conceptualization of criminal abortion laws as human rights violations when they deny women's choice shows that restrictive laws and governmental policies can be as disrespectful of women's wishes, interests, health, and bodily integrity as are rapists. Those who support and enforce such laws and policies similarly enforce their will upon women by their power of domination, in order to advance their own social, spiritual, or other purposes.

\section{HEALTH AND WELFARE}

\section{A. The Comprehensive Reproductive Health Framework}

Modern thinking on abortion law directs policy and legislation away from the historical preoccupation with criminalization and punishment, towards the protection and promotion of women's health and prevention of unsafe abortion. Particularly significant is the comprehensive framework of reproductive health that was endorsed and legitimized in 1994, through the Cairo Programme's adoption by 184 UN Member States. The Programme recognizes the importance of human rights in protection and promotion of reproductive health. ${ }^{31}$ Building on the World Health Organization's definition of health, the Cairo Programme explains that reproductive health is

[A] state of complete physical, mental and social well-being and is not merely the absence of disease or infirmity, in all matters relating to the reproductive system and to its functions and processes. Reproductive health therefore implies that people are able to have a satisfying and safe sex life and that they have the capability to reproduce and the freedom to decide if, when and how often to do so. Implicit in this last condition are the right of men and women to be informed

29. Jed Rubenfeld, The Right of Privacy, 102 Harv L. Rev. 737 (Feb. 1989).

30. R. v. Morgentaler v. The Queen 44 D.L.R.(4th) 385, at 402 (1998).

31. Cairo Programme, supra note 8, II 7.2 (1994). 
and to have access to safe, effective, affordable and acceptable methods of family planning of their choice, as well as other methods of their choice for regulation of fertility which are not against the law, and the right of access to appropriate health-care services that will enable women to go safely through pregnancy and childbirth and provide couples with the best chance of having a healthy infant. ${ }^{32}$

At Cairo, governments agreed to take steps to

[M] ake it easier for couples and individuals to take responsibility for their own reproductive health by removing unnecessary legal, medical, clinical and regulatory barriers to information and to access to family-planning services and methods. $^{33}$

Some governments took steps to reform their restrictive abortion legislation with little delay, to serve these wider reproductive health interests. For instance, Guyana enacted the Medical Termination of Pregnancy Act 1995, which is expressly based on women's needs for safe health services. The long title of the Act describes it as:

An Act to reform the law relating to medical terminations of pregnancies, to enhance the dignity and sanctity of life by reducing the incidence of induced abortion, [and] to enhance the attainment of safe motherhood by eliminating deaths and complications due to unsafe abortion.

Similarly, the Preamble to South Africa's Choice on Termination of Pregnancy Act, 1997 recognizes the constitutional right of persons "to make decisions concerning reproduction and to security in and control over their bodies" (II 2), and that:

[T] he decision to have children is fundamental to women's physical, psychological and social health and that universal access to reproductive health care services includes family planning and contraception, termination of pregnancy, as well as sexuality education and counseling programs and services. (II 4)

The Cairo Programme emphasizes that:

In no case should abortion be promoted as a method of family planning. All governments and relevant intergovernmental and non-governmental organizations are urged to strengthen their commitment to women's health . . . to reduce the recourse to abortion through expanded and improved family-planning services. Prevention of unwanted pregnancies must always be given the highest priority and every attempt should be made to eliminate the need for abortion. ${ }^{34}$

32. Id. II 7.2 .

33. Cairo Programme, supra note 8, II 7.20.

34. Id. II 8.25. The Cairo+5 Conference reiterated that "[g]overnments should take appropriate steps to help women avoid abortion, which in no case should be promoted as a method of family planning." Cairo+5, supra note 10, II 63. 
Despite the unanimity of agreement that prevention of unwanted pregnancy should "be given the highest priority," approximately one in six women of reproductive age throughout the world, nearly 230 million women, lack the means to achieve their child bearing goals..$^{35}$ The gap between the number of children women want and actually have remains sizeable. The proportion of births that are actually wanted ranges from 60 percent in Egypt and 50 percent in Mexico, to 40 percent in Kenya. ${ }^{36}$ Of the estimated 190 million pregnancies that occur worldwide each year, 51 million end in abortion, including 21 million in countries where abortion is legally restricted.

Where laws accommodate abortion but countries' lack of resources leave them dependent on overseas support for services, restrictive funding policies can also be sources of avoidable harm. For instance, the executive director of the UN Population Fund (UNFPA) has estimated that the July 2002 decision of the US government to withhold UNFPA funding would be detrimental, if not made up from other sources, since the

US\$34 million [withheld] for reproductive health and family planning would be enough to prevent: 2 million unwanted pregnancies, nearly 800,000 induced abortions, 4,700 maternal deaths, nearly 60,000 cases of serious maternal illness, and over 77,000 infant and child deaths. ${ }^{37}$

\section{B. Legal Reproductive Health Care}

The primary thrusts of reproductive health care are prevention of unwanted pregnancy and promotion of wanted pregnancy and safe childbirth, such as by methods of family planning and prevention of infertility respectively. The goal of safe lawful termination of pregnancy is only complementary to avoidance of unwanted pregnancy, arising for instance on failure of the preferred family planning alternative. However, where local law addresses abortion only through its criminal provisions, many health care providers, including obstetricians/gynecologists and other medically qualified practitioners, often presume that every abortion is axiomatically unlawful. Further, some medically unqualified health care providers confuse family planning with abortion services. The confusion may be influenced by reactionary groups and institutions, many of which are as opposed to

35. Alan Guttmacher Institute (AGl), Hopes and Realties: Closing the Gap between Women's Aspirations and Their Reproductive Realties 39 (1995).

36. AGI, id. at 24.

37. Michael McCarthy, USA Bars Funds Slated for UN Population Fund, 360 The LANCEt 313 (2002). 
contraception and sterilization as to abortion. They deliberately conflate family planning services with abortion for the purpose of attaching the stigma they perceive in abortion to family planning methods in general. Conflation and stigmatization have been successful in the U.S. where President Reagan's restrictive 1985 "Mexico City Policy," restored in January, 2001 and now known as the Global Gag Rule, prohibited funding the provision of "advice that abortion is an available option in the event other methods of family planning are not used or are not successful."38

Many countries have deliberately liberalized their abortion laws in recent decades, ${ }^{39}$ so that women and health care providers approach these procedures according to their personal ethical judgment, not in the context of potential crime. Nevertheless, where there are no explicit legal provisions for conduct of abortion, many women and health care providers presume illegality. The lack of clarity in many laws is a serious dysfunction, because too often it results in preventable death. Health care providers' apprehensions cause them to decline involvement, so that women resort to illegal and unsafe practices in cases where the law actually allows procedures by skilled, qualified providers. No law precludes abortion undertaken in the honest belief that it is necessary to save a woman's life. Further, where legislation prohibits abortion undertaken "unlawfully," courts widely acknowledge that a procedure to preserve a woman's physical or mental health against serious threat is lawful. ${ }^{40}$ A contribution that lawyers can make to reproductive health is to clarify the scope of abortion that is lawful within their jurisdictions, and inform governments, health care providers, and the general public of services that can be lawfully provided.

Even where women resort to abortion illegally, their right to health care entitles them to proper post-abortion treatment. The 1999 Cairo+5 Conference does not distinguish legal from illegal abortion in providing that "[g]overnments should . . . in all cases provide for the humane treatment and counseling of women who have had recourse to abortion." 41

38. Standard Provisions, supra note 17, at 4C-46 (d) (1) A II (emphasis added).

39. Cook, Dickens \& Bliss, International Developments in Abortion Law from 1988 to 1998, supra note 13; Cook \& Dickens, A Decade of International Change in Abortion Law: 1977-88, supra note 16.

40. R. v. Bourne, 1 King's Bench 687 (Central Criminal Court, London, 1938).

41. Cairo+5, supra note 10, II 63 (ii). 


\section{Safe and Accessible Abortion Services}

By Article 12 (1) of the International Covenant on Economic, Social and Cultural Rights ${ }^{42}$ (the Economic Covenant), member states recognize "the right of everyone to the enjoyment of the highest attainable standard of physical and mental health." In monitoring the Covenant, the Committee on Economic, Social and Cultural Rights has developed General Comment 14 on the Right to Health, which explains that the right requires the following interrelated features of health care services, namely their:

- availability (health care services have to be available in sufficient quantity);

- accessibility (services, including information, have to be physically and economically accessible to everyone without discrimination);

- acceptability (services have to be culturally appropriate, that is, respectful of the cultures of individuals, minorities and communities, and sensitive to gender and life-cycle requirements); and

- adequate quality (services have to be scientifically appropriate and of sufficient quality). ${ }^{43}$

Laws and policies that unreasonably restrict safe abortion services would not comply with this performance standard. For instance, a law or policy requiring unnecessarily high qualifications for health service providers will limit the availability of safe abortion services. Such policies may be proposed in good faith in order to ensure excellence in health care. However, it is poor public health policy, and may be a human rights violation, to jeopardize health care by requiring standards that prevent delivery of medically indicated services.

Recognizing the right to health services, governments agreed through the Cairo Programme that:

In circumstances where abortion is not against the law, such abortion should be safe. In all cases women should have access to quality services for the management of complications arising from abortion. Post-abortion counseling, education and family-planning services should be offered promptly, which will also help to avoid repeat abortions. ${ }^{44}$

42. The International Covenant on Economic, Social and Cultural Rights, adopted 16 Dec. 1966, G.A. Res. 2200 (XXI), U.N. GAOR 21st Sess. Supp. No. 16, at 49, U.N. Doc A/ 6316 (1966), 993 U.N.T.S. 3 (entered into force 3 Jan. 1976) [hereinafter the Economic Covenant].

43. General Comment on Article 12, General Comment No. 14 UN CEDSCR Comm. Econ., Soc. \& Cultural Rts., 22d Sess., at II 12, UN Doc. E/C.12/2000/4 (2000).

44. Cairo Programme, supra note 8, II 8.25. 
The Cairo Programme's promotion of reproductive health endorsed only "methods . . . for the regulation of fertility which are not against the law," since a UN Conference would not endorse an act that is criminal under a country's law, including criminal abortion. Abortions that are lawful to preserve women's lives, or to preserve their physical or mental health against serious risks should, however, be available. The Cairo Programme provides that "in circumstances where abortion is not against the law, health systems should train and equip health-service providers . . . to ensure that such abortion is safe and accessible. Additional measures should be taken to safeguard women's health." 45

Governments should therefore require health service providers to be adequately trained and equipped to deliver safe services. The World Health Organization is working to provide technical and policy guidance to governments to ensure safe and accessible abortion services. ${ }^{46}$

Laws and policies designed to limit information about safe abortion techniques and training of non-physicians in their use, in order to preserve the deterrent effect on women of the dangers of unlawful abortion, offend legal and humanitarian provisions against cruel and unusual punishment. Further, there is a denial of human rights when post-abortion care to avoid repeat abortions is obstructed. This can be due to unavailability or inaccessibility of lawful services, so that women can avail themselves only of clandestine, unskilled abortion services that are delivered without their education for future avoidance.

\section{Unsafe Abortion and Maternal Mortality}

The World Health Organization (WHO) defines "unsafe abortion" as: "a procedure for terminating an unwanted pregnancy either by persons lacking the necessary skills or in an environment lacking the minimal medical standards, or both." ${ }^{\prime 4}$

An "unwanted pregnancy" can be unwanted at its outset, such as when due to inaccessible or failed family planning or rape, or can become unwanted when a woman finds that it presents an unacceptable risk to her life or health. Opponents of abortion choice sometimes claim that pregnancy is never "unwanted," because, even though a woman may not want her pregnancy, her family, society, or government does. The claim that women should be compelled against their will to serve the wants of others

45. Cairo+5, supra note 10, II 63 (iii).

46. WhO, Safe Abortion: Technical and Policy Guidance for Health Systems (forthcoming 2002).

47. Id. at 3 . 
is an instrumental denial of their human dignity and an abuse of their reproductive capacities.

Maternal mortality, perhaps better understood in non-medical language as pregnancy-related death, includes deaths due to unsafe abortion, as well as death to women in and following childbirth. WHO defines maternal death as:

[T] he death of a woman while pregnant or within 42 days of termination of pregnancy, irrespective of the duration and site of the pregnancy, from any cause related to or aggravated by the pregnancy but not from accidental or incidental causes or its management. ${ }^{48}$

Accordingly, death to "a woman while pregnant . . . irrespective of the duration ... of the pregnancy" caused by an unskilled abortion is classified as a maternal death, as is death within forty-two days following abortion due to related complications.

Estimates of maternal deaths vary, depending on the sophistication of calculation, the time period of measurement, and classification practices. Calculation is difficult in countries that have no official registration of numbers or causes of deaths. However, an authoritative estimate of 1995 figures is that the annual toll was 515,000 maternal deaths worldwide, an average rate of over 1,400 deaths each day. ${ }^{49}$ In 1994 , WHO estimated that worldwide, about 13 percent of the 515,000 pregnancy-related deaths, almost 67,000, were due to unsafe abortion. ${ }^{50}$ A 1997 WHO report estimating unsafe abortion presented a total of about 78,000 resulting deaths. ${ }^{51}$ The percentage of maternal deaths due to unsafe abortion will vary according to the circumstances in each country. Beyond the deaths due to unsafe abortion are the incalculable health consequences and disabilities, such as infertility resulting from unskilled abortion.

A high-risk pregnancy may be attributable to a predisposing risk factor, such as a woman's physical condition or disease. A predisposing risk factor, for example, may be an adolescent's pelvic underdevelopment due to malnutrition. Medical research has shown that pregnancy aggravates and is aggravated by diseases such as malaria, hepatitis, sexually transmitted infections including HIV/AIDS, anemia including sickle cell anemia, jaundice, tuberculosis, and heart disease. Sickle cell anemia, for example, makes pregnancy and childbirth very risky, painful, and difficult. If a pregnant woman dies of such a disease or condition, the death is classified

48. WhO, The Tenth Revision of the International Classification of Diseases (ICD-10) (1992).

49. Id.

50. Who, United Nations Children's Fund and United Nations Population Fund, Maternal Mortality in 1995: Estimates Developed by WHO, UNICEF and UNFPA (2001).

51. WHO, Unsafe Abortion Report, supra note 1 at 8. 
as an indirect maternal death. The risk of death during pregnancy, aggravated by these indirect medical causes, can be greatly reduced by safe abortion even though abortion will not reduce the more general risks associated with these diseases. If proper abortion care fails to save the life of a woman suffering a predisposing risk factor, the death is not due to "unsafe abortion."

In developing country settings, studies indicate that 20 percent or more of all maternal deaths are due to indirect causes. ${ }^{52}$ The percentage varies among countries, depending upon the prevalence and severity of the diseases that are the indirect medical causes. Moreover, these diseases and conditions are more prevalent in some subgroups of women than others. For example, sickle cell anemia is common in Black women. ${ }^{53}$ As a result, the rates at which therapeutic abortion is medically justified will vary according to the prevalence and severity of such diseases and risk factors.

\section{E. The Public Health Setting}

Each instance of a woman's death or disability due to unsafe abortion is lamentable and represents a failure, whether of prevention and control of unplanned pregnancy, access to medical care or, for instance, human rights protection. The Beijing Platform placed unsafe abortion on an additional plane, however, in requiring that governments "deal with the health impact of unsafe abortion as a major public health concern." 54 The public health approach opens a middle path between clinical health care based particularly on human reproductive physiology, and refined philosophical speculation that addresses such historical issues as the moral and spiritual status of human embryos and modern issues in feminist scholarship and analysis. The new approach opens a way, which parallels the growth of evidencebased clinical medicine, towards evidence-based social policy founded on public health sciences. These include epidemiology, which addresses the study of epidemics not limited to diseases, but including such phenomena as unplanned pregnancy and resort to abortion, and sociological studies of communal impacts, attitudes, behaviors, and motivations.

For instance, public health studies can identify the impact on a community hospital of coping with the needs of women suffering complications from unsafe abortion. Such studies can also show the negative impact on other women's access to public hospital services for routine prenatal

52. Id. at 119 .

53. Mahmoud F. Fathalia, From Obstetrics and Gynecology to Women's Health, 93 (1997).

54. Beijing Platform, supra note 9, II 106 (j). 
care and management of mothers and children at and following complicated deliveries, and other patient's access to general emergency care. Studies can also test whether restrictive laws prevent abortions or simply direct women to unskilled providers and women's self-administered interventions, and whether liberalized laws induce couples to be casual regarding use of family planning alternatives, or reduce the communal incidence of pregnancy-related mortality and morbidity.

International experience discloses several public health and social science studies that illuminate how the operation of laws has affected the incidence of abortion and access to safe services. For instance, the health consequences of liberalized abortion laws, and the health costs to women of repressive abortion laws, are most clearly demonstrated in data from Romania. Legislation that took effect in 1990 reversed the severely repressive law that the former administration introduced in 1966. During the quarter century of pro-natalist policies, abortion-related maternal deaths per 100,000 live births rose from under 20 in 1965 to between 120 and 150 each year between 1982 and 1989. As a percentage of maternal deaths from all causes, abortion-related deaths rose from about 20 percent to nearly 90 percent over that period. The rate of maternal mortality, which in 1966 was comparable to that of most other Eastern European countries, was at least ten times higher than in any other European country by 1989. In contrast, in the year following legalization of abortion, the maternal mortality rate fell almost 50 percent..$^{55}$ The statistics show how restrictive abortion laws can cost countless women their right to life.

In 1988, the Supreme Court of Canada reviewed a social science study commissioned by the government on the operation of the prevailing abortion law. ${ }^{56}$ The government initiated this law in 1969, claiming that its provisions would serve women's needs for safe access to therapeutic services. The provisions introduced in 1969, which were in the Criminal Code, identified hospitals that were eligible to perform lawful procedures, on condition of approval by hospital therapeutic abortion committees composed of at least three doctors. On review of the actual availability of services between 1969 and 1977, the Court observed that no eligible hospital or health facility in the country had any legal duty to establish such a committee. One province has no hospital with a committee, and 40 percent of Canadian women lived outside areas whose hospitals were eligible to establish committees. The Court reviewed evidence that many

55. Charlotte Hord et al., Reproductive Health in Romania: Reversing the Ceausescu Legacy, 22 Stud. Fam. Plan. 231 (1991).

56. Canada, Report of the Committee on the Operation of the Abortion law (chaired by Robin F. Badgley) (1997) [hereinafter the Badgley Report]. 
eligible hospitals with committees refused to treat women who resided outside their catchment areas, and some maintained restrictive quotas for those who lived inside. These included the larger university-affiliated teaching hospitals in major population centers, which felt obliged to offer students a full variety of different exposures to gynecological practice. Several hospitals with committees included non-physician members opposed to abortion, such as hospital chaplains, and approved few if any applications.

The Court found that overall, abortion services indicated on health grounds were inequitably restricted, and often harmfully delayed into the second trimester of pregnancy, so obstructing women's right to timely health services and therefore to security of the person guaranteed by the constitution. The Court struck down the Criminal Code abortion provisions as deceptive in their claim to protect women's health, and unconstitutional. ${ }^{57}$ They have not been replaced, in deference to women's right to health care and for apprehension that public health studies would again demonstrate the dysfunction and injustice of approaching therapeutic health care through exemptions from criminal laws.

\section{HUMAN RIGHTS, HUMAN DIGNITY, AND SOCIAL JUSTICE}

The most recent stage in evaluation of abortion laws, motivated by human rights considerations, has been implicit in the concept of reproductive health, because the right to the highest attainable standard of health, of which reproductive health is part, is central to the protection and promotion of human rights. In practice, human rights are interrelated and interdependent, since a violation of any one is frequently a violation of another. Indeed, the very conventions that express these rights are themselves interrelated. Not only individual rights but also the national constitutions and international conventions that express them may be permeable. Human rights tribunals hearing complaints of discrimination under one human rights convention may consider whether there has been discrimination with respect to rights protected in other conventions. ${ }^{58}$

Particularly relevant to reproductive health and self-determination are rights relating to: life, liberty, and dignity; non-discrimination and due respect for difference; and citizenship. These rights are progressively being applied to the special circumstances of women, who for obvious physiological

57. R. v. Morgentaler v. The Queen 44 D.L.R. (4th) 385, at 402 (1998).

58. Broeks v. The Netherlands, Communications No. 172/1984, U.N. GAOR, 42nd Sess., Supp. No. 40 at 139, U.N. Doc. A/42/40 (1987). 
reasons bear the overwhelming burden of unplanned pregnancy and who, in protection of their lives and health in many parts of the world, most directly confront restrictive abortion laws and policies. The development of the content and meaning of these rights in the context of abortion can vary, especially given the distinct cultural and political approaches to sex and gender. $^{59}$

\section{A. Life, Liberty, and Dignity}

\section{Life and Survival}

The right to life has been invoked to support opposing claims, some on behalf of embryos and fetuses and others on behalf of women, although these rights are not necessarily in opposition, and usually coincide in the case of planned pregnancy. In controversies over abortion, courts often distinguish moral and spiritual claims made on behalf of unborn children from the legal claims they uphold on behalf of pregnant women, but some legislation explicitly recognizes legal claims made on behalf of prenatal life. Moreover, some courts recognize interests of the state itself in prenatal life, and some consider these interests potentially superior to the interests of a pregnant woman. However, courts invariably interpret laws to provide that women's interests prevail when continuation of pregnancy endangers their lives. In 1992, for instance, the Irish Supreme Court held that the equal rights to life of a pregnant woman and her fetus, set out in the Irish Constitution, must be balanced to permit abortion when necessary to protect the woman's life. ${ }^{60}$

\section{a. Legal Protection of Life from Conception or Birth}

Everyone may legitimately claim respect for and protection of their human rights between complete live birth and death. Strongly contested, however, is whether the same claim may be made on behalf of a fertilized ovum from conception. In parts of the world, the contest has been particularly animated since 1869, when the Roman Catholic Church adopted the view that human life warrants full protection from conception. ${ }^{61}$ Historical law has not recognized this claim.

59. Antoinette Sedillo Lopez, Comparative Analysis of Women's Issues: Toward a Contextualized Methodology, in Global Critical Race Feminism 67-80 (Adrien K. Wing ed., 2000).

60. The Attorney General v. X and Others, [1992] 1 IR 1 (Ir.S.C.) 54-55.

61. J. Kenyon Mason, Medico-Legal Aspects of Reproduction and Parenthood, 2 ed. 1998 at 109. 
The highest courts in many countries have declared that legal protection of human beings originates at live birth. In the Anglo-Saxon common law tradition, a child does not become a human "in being" (that is, a "human being" or "person") until it has completely proceeded in a living state from the body of its mother. ${ }^{62}$ International human rights tribunals also generally adhere to the "born alive" rule, according to which a claim may be pursued for prenatal injury only on condition that the fetus is born alive.

Several national courts have held that their permissive abortion laws are compatible with the right to life provisions of either the European Convention on Human Rights $^{63}$ (the European Convention) or the International Covenant on Civil and Political Rights ${ }^{64}$ (the Political Covenant), and sometimes both. The French Conseil d'État held that France's liberal abortion law, which permits therapeutic abortion in broadly defined terms including a woman's distress, is compatible with the right to life articles of the European Convention (Article 2) and the Political Covenant (Article 6). ${ }^{65}$ A Dutch court has also upheld the similar Dutch abortion law on the same grounds. ${ }^{66}$ The Constitutional Court of Austria, in upholding the Austrian Penal Code provision permitting abortion on request during the first trimester of pregnancy and on specified grounds thereafter, interpreted Article 2 of the European Convention not to recognize a right to life before live birth. ${ }^{67}$

The European Commission respected this interpretation in upholding the British Abortion Act, 1967,68 as have subsequent courts in several European countries. ${ }^{69}$ The Commission found it contrary to the object and purpose of the European Convention that the right to life of the person already born would be considered subject to limitation in favor of the unborn. The British Abortion Act, 1967 accommodates abortion on grounds of the woman's life or health, and when continuance of pregnancy would

62. Rebecca J. Cook, International Protection of Women's Reproductive Rights, J. OF INT'L Law and Poltics 24(2) 645, 688-96 (1992).

63. European Convention for the Protection of Human Rights and Fundamental Freedoms (opened for signature 4 Nov. 1950), 213 U.N.T.S. 221 (entered into force 3 Sept. 1953) [hereinafter the European Convention].

64. International Covenant on Civil and Political Rights, G.A. Res. 2200 (XXI), 21 U.N. GAOR Supp. (No. 16) at 52, U.N. Doc. A/6316 (1966), 999 U.N.T.S. 171 (entered into force 23 Mar. 1976) [hereinafter the Political Covenant].

65. Judgment of 21 Dec. 1990, 7 Revue Française de Droit Administratif 208 (1991).

66. Juristenvereniging Pro Vita v. De Staat der Nederlanden (Ministerie van Welzijn, Voldsgezondheid en Cultuur) [1990] NJ 2986 (8 Feb. 1990) (The Court, The Hague).

67. Judgment of 11 Oct. 1974, Erklrungen des Verfassungsgerichtshofs 221 (Constitutional Court of Austria).

68. Paton v. United Kingdom, 3 E.H.R.R. 408 (1980) (Eur. Comm'n Hum. Rts.).

69. Principles of Medical Law 643-44 (lan Kennedy \& Andrew Grubb eds., 1998). 
injure the physical or mental health of the pregnant woman's existing children. The Commission did not find it necessary to decide whether Article 2 of the European Convention recognizes a "right to life" of a fetus, although subject to limitations.

The question remains, however, whether a pregnant woman's rights can be limited by the interest of the state itself in unborn human life. Attorneys General, Ministers of Justice, and other state officers, such as police officers, may initiate legal proceedings, for judicial declarations or against women and those who perform abortion, to defend the public or state interest they claim exists in human life in utero.

It is generally recognized that international human rights conventions are not applicable before birth of a human being. During the preparatory debates on the Political Covenant, for instance, amendments that were proposed to protect the right to life from the moment of conception were rejected ${ }^{70}$ and Article 6 (1), addressing the right of every "human being," is understood in this light. When the Convention on the Rights of the Child ${ }^{71}$ (the Children's Convention) was being drafted, the same question was debated. The outcome appears in the Preamble to the Convention, which invokes language in the Declaration that preceded the Convention. ${ }^{72}$ The Preamble "[Bears] in mind that, as indicated in the Declaration of the Rights of the Child, 'the child, by reason of his physical and mental immaturity, needs special safeguards and care, including appropriate legal protection, before as well as after birth.'"173

However, Article 1 provides that, for purposes of the Convention, "a child means every human being below the age of eighteen years unless, under the law applicable to the child, majority is attained earlier." Accordingly, the enforceable provisions of the Convention are widely understood to retain the historical understanding that legally protected status as a human being begins at live birth.

The Convention gives no guidance to what the Preamble means by "appropriate legal protection, before as well as after birth." Such protection might include provision of reasonable prenatal care, nutrition and essential obstetric care to ensure safety in delivery and care for the newborn. ${ }^{74}$

\footnotetext{
70. Maxime Tardu, Relationship Between Human Rights and Population Issues in United Nations, in United Nations, Population and Human Rights 54, 61 (1990).

71. Convention on the Rights of the Child (adopted 20 Nov. 1989), G.A. Res. 44/25 U.N. GAOR, 44th Sess., Supp. No. 49 at 167, U.N. Doc. A/44/49 (1989) (entered into force 2 Sept. 1990) [hereinafter the Children's Convention].

72. Declaration of the Rights of the Child, G.A. res. 1386 (XIV), 14 U.N. GAOR Supp. (No. 16) at 19, U.N. Doc. A/4354 (1989).

73. Children's Convention, supra note 71, at Preambular $\mathbb{I I} 9$.

74. Save the Children, State of the World's Newborns (2001).
} 
However, not all states whose laws require protection of human life from conception accept their own legal obligation to provide resources for these purposes.

The American Convention on Human Rights ${ }^{75}$ (the American Convention) provides that the right to respect for life "shall be protected by law and, in general, from the moment of conception."76 The words "in general" indicate that the Convention does not necessarily give priority to unborn life over the life or health of born persons, since protection of prenatal life does not clearly withdraw protections from born persons. The provision in the Convention may require protection of unborn life against injuries, for instance, that would impair the life of a human being, but not necessarily limit abortion to preserve the life or health of a woman, or indeed of other children in her family.

In contrast, the American Declaration on the Rights and Duties of Man ${ }^{77}$ does not address unborn life. It recognizes the right to life of every "human being." The Declaration begins its Preamble with the observation that "All men are born free and equal," suggesting that freedom and equality are conditional on live birth. In 1981, the Inter-American Commission on Human Rights held the American Declaration inapplicable to the unborn, and determined that the 1973 US Supreme Court decision in Roe v. Wade, ${ }^{78}$ which recognized women's constitutional right to abortion before fetal viability, was compatible with the Declaration. ${ }^{79}$

Courts often observe that their task is to interpret the law in accordance with their legal traditions, and not to engage in moral or spiritual discourse. For instance in 1997, finding that its state Civil Code, which gives rights to a "person," awards no legal personality to a fetus, the Louisiana Supreme Court observed that this refusal

constitutes no moral or philosophical judgment on the value of the fetus, nor any comment on its essential humanity. Rather, the classification of 'person' is made solely for the purpose of facilitating determinations about the attachment of legal rights and duties. 'Person' is a term of art. ${ }^{80}$

75. American Convention on Human Rights, signed 22 Nov. 1969, O.A.S. T.S. No. 36, O.A.S. Off. Rec. OEA/Ser.LV/II.23 doc.21 rev.6 at 25 (1979) (entered into force 18 July 1978), reprinted in Basic Documents Pertaining to Human Rights in the Inter-American System (1992) [hereinafter the American Convention].

76. Id. art. 4 (emphasis added).

77. American Declaration on the Rights and Duties of Man, signed 2 May 1948, OEA/Ser.L./ V/II 71, at 71 (1988).

78. Roe v. Wade, 410 U.S. 113 (1973).

79. Case 2141, Inter-Am. C.H.R. 25, OEA/ser. L/V/1154, Doc. 9 rev. 1 (1981) (InterAmerican Commission of Human Rights).

80. Wartelle v. Women's and Children's Hosp., Inc., 705 So. 2d 778, 780 (1997). 
In South Africa, the 1996 Constitution provides in section 11 that "everyone has the right to life," but a year later, the country enacted the liberal Choice on Termination of Pregnancy Act. The Minister of Health was sued for declarations that the Act is unconstitutional, on grounds that a fetus is included in the expression "everyone," and that the life of a human being starts at conception. The judge refused the declarations on the ground that "everyone" is a legal alternative expression to "every person," and on historical grounds legal personhood commences only at live birth. ${ }^{81}$ The judge did not rule on the claim regarding the beginning of human life, explaining that even if the claim was biologically correct, it did not justify the conclusion that the human life that had begun was that of a legal person. He adopted the observation that: "the question is not whether the conceptus is human but whether it should be given the same legal protection as you and me." 82

The judge echoed many other courts that have addressed abortion interests by observing that the judicial task is not to resolve conflicts about biological facts or moral or spiritual values, but to make determinations of law, according to legal traditions and contexts, guided but not governed by social effects.

Legal indications of the status of human life at an early stage following conception come from the area of medically assisted reproduction. Modern techniques include in vitro fertilization and storage (cryopreservation) of embryos. In the United Kingdom, the Human Fertilisation and Embryology Act $1990^{83}$ requires that embryos must usually be let perish not later than five years after their creation. In mid-1996, under the direction of the Human Fertilisation and Embryology Authority, about 3,300 stored embryos were caused to perish in accordance with the 1990 Act. $^{84}$ This public mandate for discarding embryos is consistent with the view that, whether they are located in storage or in utero, they warrant some degree of respect, but not that due to "human beings" as conventionally understood in law.

In several countries, however, the intention to give effect to religious faith as understood in the Roman Catholic tradition is expressed in constitutional provisions or legislation that declare the protection of human life from conception. For example, the Constitutions of Ireland, ${ }^{85}$ the

81. Christian Lawyers Association of South Africa v. The Minister of Health, 1998 (11) BCLR $1434(\mathrm{~T})$.

82. Id. II 8, quoted in Williams, supra note 61 , at 78 .

83. United Kingdom, Human Fertilisation and Embryology Act, 1990, Statutes, ch. 37, at 1930.

84. Micheal D. Lemonick, Sorry, Your Time Is Up, 148 Time MAg., 12 Aug. 1996, at 41.

85. Constitutions of the Countries of the World vol. IX (Constitutions of the World), Const. of Ireland, art. 40(3)(3) (Albert P. Blaustein \& Gisbert H. Flanz eds., 1997). 
Philippines $^{86}$ and the Mexican state of Chihuahua ${ }^{87}$ acknowledge the right to life from the moment of conception. The Czech Charter of Fundamental Rights and Freedoms contains a provision that human life is "worthy of protection already before birth." ${ }^{\prime 8}$

In 1994, the Constitutional Court of Colombia recognized that the right to decide the number and spacing of one's children is protected by the 1991 Constitution. ${ }^{89}$ However, acting in the Roman Catholic tradition, it held that the right was not infringed by the criminalization of abortion, because this right can be exercised only until the moment of conception..$^{90}$ In 1997, the Polish Constitutional Tribunal rejected national legislation enacted in 1996 to deal with family planning, human embryo protection, and legal conditions for abortion, holding that constitutional provisions protect human life in every phase of its development. ${ }^{91}$ The Tribunal accepted rights of abortion when women's lives are endangered, but considered the 1996 permission of economic and social grounds for abortion, such as difficult life conditions or personal situations, too vague to justify sacrifice of prenatal life.

The Constitutional Courts of Germany and Hungary have experienced similar struggles between the protection of prenatal life and of women's human rights. In 1975, the German Constitutional Court held that a fetus is not the equivalent of a person, but that it enjoys some limited constitutional protection because its life has an independent legal value. ${ }^{92}$ In 1993, the Court upheld this approach, but gave express recognition to the constitutional protection of women's human rights to dignity, physical integrity, and personal development. ${ }^{93}$ The outcome of the Court's struggle was to uphold legislation allowing availability of abortion on restricted grounds. In 1998, the Hungarian Constitutional Court addressed the balance between women's human dignity and interests in prenatal life ${ }^{94}$ in Hungary's 1992 legislation allowing abortion on request in the first trimester. ${ }^{95}$ The Court required the

86. Constitutions of the WorLd, supra note 85 , Const. of Philippines, art. II, $\S 12$, at Vol XV.

87. Political Constitution of the Mexican State of Chihuahua, art. 5 (1994).

88. Constitutions OF THE WORLD, supra note 85, Charter of Fundamental Rights and Freedoms, art. 6, vol. V.

89. Constitutions of the world, supra note 85, Constitution of Colombia, Title II, Ch. 2, art. 42, vol. IV.

90. Decision C-133/94 of the Constitutional Court, 17 Mar. 1994 (Colombia).

91. Ruling K 26/96 of the Constitutional Tribunal, 28 May 1997 (Poland).

92. Judgment of 25 Feb. 1975, Bundesverfassungshericht (Constitutional Court) 39 BverfGE 1 (W. Germany).

93. Judgment of 28 May 1993, 88 BverfGE (Second Senate) (Germany).

94. Judgment 48/1998 (IX.23) AB Hatarozat Official Legal Gazette (Magyar Kozlony 1998/ 105). 6654-6673 (Const. Court of Hungary). See generally Center for Reproductive LaW and Policy, Women of the World: Laws and Policies Affecting Their Reproductive Lives-East Central Europe, 2000, 60-61.

95. Act LXXIX of 1992, "Protection of Fetal Life." 
national parliament to clarify the legal test of "grave crisis" that justifies abortion..$^{96}$ In 2000, legislation provided that grave crisis means the presence of factors liable to cause profound physical or mental distress, or unacceptable social circumstances. ${ }^{97}$

\section{b. Positive Obligations to Protect Life}

The history of the right to life in the development of national and international law ${ }^{98}$ has been to ensure the right to fair legal proceedings before imposition of capital punishment. ${ }^{99}$ However, the right to life is emerging from this narrow historical origin to require states to take positive steps to promote life and survival and to advance safe motherhood. ${ }^{100}$ The European Commission of Human Rights, for instance, has considered a complaint alleging that a governmental vaccination program that resulted in the deaths of some vaccinated babies violated their right to life. Article 2 of the European Convention provides that "everyone's right to life shall be protected by law." On the merits of this case, the Commission found that appropriate measures to protect life had in fact been taken. Had it found otherwise, however, the defendant state would have been found in breach of its duty to safeguard the right to life. ${ }^{101}$

The Commission has also addressed a complaint concerning a woman who died in childbirth. Although the case was held inadmissible on technical grounds, the Commission nevertheless emphasized that the right to life has to be interpreted to require states to take steps not only to prevent intentional killing, but also to protect life against unintentional loss. ${ }^{102}$ In monitoring the Political Covenant, the UN Human Rights Committee has explained that "the expression 'inherent right to life' cannot properly be understood in a restrictive manner, and the protection of this right requires that states adopt positive measures." ${ }^{103}$

The Inter-American Court of Human Rights, holding the government of

96. Judit Sandor, From Ministry Orders towards the Constitutional Debate: Lessons Drawn from the Past 50 Years of Abortion Laws in Hungary, 18 Med. \& THE Law 389 (1999).

97. Act LXXXVII of 2000, "Law on the Protection of the Life of the Fetus."

98. Manfred Nowak, U.N. Covenant on Civil and Political Rights: CCPR Commentary 103-22 (1993).

99. It is commonly observed that anti-abortion advocates who invoke the Right to Life tend to favor capital punishment, and that "many States in which religion has a powerful voice in governmental policy-making retain the judicial death penalty"; JOHN K. MASON, Human Life and Medical Practice 5 (1988).

100. Rebecca J. Cook \& Bernard M. Dickens, Advancing Safe Motherhood through Human Rights 27-29 (2001).

101. Association X. v. United Kingdom, Application No. 7154, Decision 12 July 1978, in 14 Decisions and Reports 31 (June 1979) (European Commission of Human Rights).

102. Tavares v. France, Application No. 16593/90, Decision 12 Sept. 1991 (European Commission of Human Rights) (unreported).

103. Human Rights Committee General Comment 6: The Right to Life (art. 6), CCPR 16th Sess. (1982). 
Guatemala responsible for tolerating inhuman treatment and deaths of street children, explained that:

In essence, the fundamental right to life includes, not only the right of every human being not to be deprived of his life arbitrarily, but also the right that he will not be prevented from having access to the conditions that guarantee a dignified existence. States have the obligation to guarantee the creation of the conditions required in order that violations of this basic right do not occur and, in particular, the duty to prevent its agents from violating it. ${ }^{104}$

Where states neglect to provide the means necessary to prevent women from dying of pregnancy-related causes, such as treatment for unsafe abortion or provision of skilled attendance at childbirth, they are failing in their obligation to ensure women's "access to the conditions that guarantee a dignified existence."

\section{Liberty and Security}

Many national constitutions and human rights conventions protect individuals' "liberty and security" of the person. A constitution may explicitly address the security of the person in the context of reproductive integrity. For example, the 1997 South African Constitution provides in section 12(2) that

Everyone has the right to bodily and psychological integrity, which includes the right

(a) to make decisions concerning reproduction;

(b) to security in and control over their body. ${ }^{105}$

Some courts distinguish rights to personal liberty from rights to security, ${ }^{106}$ considering rights to security to be narrower. Security interests relate to denial of health care services that leaves individuals at risk of their lives or of grave impairment to their health. The Supreme Court of Canada held that impaired access to therapeutically indicated abortion violates women's rights to security of their person. ${ }^{107}$ Several constitutional courts, including those of Austria, ${ }^{108}$ France, $^{109}$ Italy, $^{110}$ and the Netherlands, ${ }^{111}$ have gone beyond

104. Villagran Morales v. Guatemala, Series C No 63, 19 Nov. 1999, II 144 (Inter-American Court of Human Rights).

105. Constitutions OF THE WORLD, supra note 85, S. Afr. Const. § 12(2).

106. R. v. Morgentaler v. The Queen 44 D.L.R. (4th) 385, at 402 (1998).

107. Id. at 417, 420, 461, 482, 500 (Dickson, C.J.C. \& Beetz, Estey, Lamer, and Wilson, J.J., respectively).

108. Constitutional Court of Austria, supra note 67.

109. Decision 74-54 DC, Judgment of 15 Jan 1975, Loi sur l'interruption volontaire de grossesse (Constitutional Convention of France) [law relating to the termination of pregnancy].

110. Judgment No. 108/81 of 25 June 1981, Corte Costituzionale, 57 Raccolta Ufficiale della Corte Costituzionale 823 (1981).

111. Juristenvereniging Pro Vita v. De Staat der Nederlanden, supra note 66. 
recognition of security interests, however, to find that accommodating abortion laws serve women's right to liberty. These courts recognize that women seek to control their fertility not simply to secure their lives and health, but because lack of control incapacitates them from pursuing the personal, social, spiritual, economic, and other opportunities in life that they value.

Some courts are importing notions of health into the meaning of the right to security of the person. For example, the Supreme Court of Canada heard evidence that the requirement of prior approval by a hospital abortion committee caused an average delay of eight weeks between a pregnant woman's first contact with a physician and her therapeutic abortion. ${ }^{112}$ Although the constitutional Charter of Rights and Freedoms does not have an explicit right to health care, the Court found that the harmful physical and emotional health impact of the delay was a denial of the right to security of the person, so that the law requiring committee approval for abortion was unconstitutional. ${ }^{113}$

In countries with liberal laws, courts are beginning to address the lack of provision of abortion services particularly when they are necessary for therapeutic reasons. In the United States, for instance, since the "Hyde Amendment" of $1976,{ }^{114}$ Congress has passed legislation every year excluding abortion from health care funding for low-income women, except in limited cases. Federal funding of abortion is limited to instances where the woman's life is at stake or where pregnancy is the result of rape or incest. ${ }^{115}$

However, several state courts have struck down statutes restricting abortion funding for low income women. ${ }^{116}$ President Clinton twice vetoed bills passed by Congress banning what they called "partial birth" or late term abortions, because the bills lacked an exception for preservation of women's health. The Supreme Court has found similar state laws unconstitutional for the same reason. ${ }^{17}$

Negative rights to liberty or security by resort to health care services restrain police and other governmental obstruction of abortion procedures of which women can avail themselves, but positive rights require governments to provide women with reasonable access to safe services. Since

112. R. v. Morgentaler v. The Queen 44 D.L.R.(4th) 385, at 402 (1998); Thornburgh v. American College of Obstetricians and Gynecologists, 106 S.Ct. 2196 (1986).

113. R. v. Morgentaler, at 404.

114. Public Law 94-439, § 209 (1976).

115. Departments of Labor, Health and Human Services, Education and Related Agencies Appropriations Act, Public Law 105-78 (1998).

116. Linda M. Vanzi, Freedom at Home: State Constitutions and Medicaid Funding for Abortions, 26 New Mexico L. Rev. 433 (1996).

117. Stenberg v. Carhart, 530 U.S. 914120 S. Ct. 2597 (2000) (Nebraska statute that bans a particular abortion procedure, and is similar to statute in thirty other states, violates a woman's constitutional right to end a pregnancy). 
abortion is a medical procedure, there is no violation of negative rights by legal limitation of services to those performed by, or under the direction of, medically qualified practitioners. The contrast between negative and positive rights is evident in the United States, where the Supreme Court has found the negative right to be constitutionally protected, ${ }^{118}$ but has upheld limitations on governmental provision and funding of services. ${ }^{119}$

A more blatant threat to liberty, and often security, arises from imprisonment. Through the Beijing Platform, governments agree to "consider reviewing laws containing punitive measures against women who have undergone illegal abortions." ${ }^{20}$ Review requires countries that imprison women for undergoing or attempting their own abortion, such as Chile ${ }^{121}$ and Nepal, ${ }^{122}$ to reform their penal laws. Prosecution under such laws is clearly influenced by governmental philosophies and policies. For instance, in Chile in the early 1980's under the Pinochet regime, an estimated 1,000 prosecutions each year were reported against women having abortions, many following reports to police from hospitals to which women had gone for treatment for abortion-related complications. Many of these women were young, poor, unmarried, rural immigrants to larger cities and pregnant following rape. In 1983, fifteen out of 230 women sentenced to imprisonment (6 percent) were convicted on abortion charges. However, the subsequent administration was more hesitant to press charges and seek imprisonment. In 1993, only ten of 423 women sent to prison (2.4 percent) were convicted on abortion charges. ${ }^{123}$ Nevertheless, by reference to most other countries, Chilean statistics of prosecutions of women for abortion remain unusually high.

In Nepal, a rough 2002 estimate is that 100 women are in prison for abortion. ${ }^{124}$ However, a 15 -year-old girl sentenced to 20 years' imprisonment following an abortion, compelled by her family when she became pregnant following rape by a family member, was released at an appeal hearing in

118. Roe v. Wade, 410 U.S. 113 (1973).

119. Harris v. McRae, 448 U.S. 297 (1980); Webster v. Reproductive Health Servs., 492 U.S. 490 (1989); Planned Parenthood of Southeastern Pennsylvania v. Casey, 505 U.S. 833 (1992) (US Supreme Court).

120. Beijing Platform, supra note 9, II 106(k).

121. Center for Reproductive Law and Policy \& The Open Forum on Reproductive Health and Rights, Santiago, Women Behind Bars: Chile's Abortion laws-A Human Rights Analysis (1998); Lydia Casas-Becerra, Women Prosecuted and Imprisoned for Abortion in Chile, 9 Reproductive Health Matters 29, 30 (May 1997).

122. Geeta Ramaseshan, Women imprisoned for abortion in Nepal: Report of a Forum Asia Fact-Finding Mission, 10 Reproductive Health Matters 133 (1997); Center for Reproductive Law and Policy and the Forum for Women, Law and Development, Abortion in Nepal: Women IMPRISONED (2002).

123. Casas-Becerra, supra note 121.

124. Ramaseshan, supra note 122. 
2000 following international pressure. ${ }^{125}$ Perhaps due to recognition of the injustice Nepalese women have suffered, the legislature subsequently liberalized the law to allow abortion on extended grounds, and to repeal provisions penalizing women for undergoing legal abortions. ${ }^{126}$ France has also eliminated penalties against women who induce their own abortions, ${ }^{127}$ thus ensuring the legality of self-administration of abortifacient drugs approved for prescription in France in 1988. ${ }^{128}$

Evidence of abuses of women's physical security due to restrictive abortion laws can influence democratic law reform. In Ireland, for instance, public reaction against judicial obstruction of access to abortion services by abused young girls in highly publicized cases triggered intense political action for legislative liberalization, resulting in a referendum that approved constitutional reform. ${ }^{129}$ Similarly, public outrage in Bolivia against judicial denial of abortion for an 11-year-old rape victim resulted in a legislative bill to ease the restrictive Penal Code, on grounds of promotion of human rights. ${ }^{130}$

\section{Human Dignity and Freedom from Inhuman and Degrading Treatment}

Related to the human right to liberty and security of the person is the right to freedom from torture and from inhuman and degrading treatment. The Beijing Platform recognizes that women are vulnerable to torture in sexual and other ways because of their low status in almost every society, ${ }^{131}$ and requires governments to take preventive action. ${ }^{132}$ Rape and domestic violence account for about 5 percent of the disease burden in women ages 15-44 in developing countries, and about 19 percent in industrial countries. ${ }^{133}$ Violations of human dignity result in many injuries, including to self-confidence and self-esteem, that are not quantifiable as disease burdens.

125. The Story of Min Min Lama, available at http:/www.tribute.nl/wpf/uk/content/special.html (visited 1 Feb. 2000); see also IPPF Annual Report 1999 at 13, available at http:// www.ippf.org/annualreport1999/safety.htm.

126. The 11 th revision of Muluki Ain 2059 B.S. (the Law of the Land 2002 AD).

127. Law No. 93-121 of 27 Jan. 1993, 20 Annual Rev. Population L. 15 (1993) (codified as Law No. 93-121 of 27 Jan 1993, J.O., 30 Jan. 1993, p. 1576-88).

128. Order of 28 Dec. 1988, 1 Journal Officiel de la Republique Francalse 465 (12 Jan. 1989) summarized in 40 Int'L Digest Health Legis. 430 (1989).

129. Medb Ruane, The Irish Referendum: The End of Roman Rule, Conscience 23(1) 9-10 (2002).

130. Teresa L. Monje \& Anna M. DeNicola, Ignoring the Anguish, 3 ConsCIENCE 21, 24 (1999).

131. Beijing Platform, supra note 9, II 135.

132. Id. II 107(q).

133. World Bank, World Development Report 1993: Investing in Health (1993). 
The Beijing Platform condemns "sexual slavery, rape, sexual abuse and forced pregnancy." 134 Forced pregnancy includes denial and obstruction of abortion following pregnancy by rape. The Cairo Programme urges governments:

[T]o identify and condemn the systematic practice of rape and other forms of inhuman and degrading treatment of women as a deliberate instrument of war and ethnic cleansing and take steps to assure that full assistance is provided to the victims of such abuse for their physical and mental rehabilitation. ${ }^{135}$

It should be remembered that Nazi governments in Europe before 1945 forced abortion of mixed-race and other "impure pregnancies," and forced continuation of "racially pure" pregnancy by prohibition of abortion. This was part of their policies to promote racial purification. The wishes of the pregnant women were legally irrelevant, since abortion, both compelled and prohibited, was an instrument of state policy. ${ }^{136}$ The inhumanity of forced continuation of pregnancy was addressed in the 1996 response of the UN Human Rights Committee to the Report of the Government of Peru, submitted under the Political Covenant, which the Committee monitors. In its Concluding Observations, the Committee expressed concern "that abortion gives rise to a criminal penalty even if a woman is pregnant as a result of rape and that clandestine abortions are the main cause of maternal mortality." ${ }^{137}$ The Committee found that the criminal law subjected women to inhumane treatment contrary to Article 7 of the Covenant, and was possibly also incompatible with Article 3 on equal entitlement of men and women to the enjoyment of rights, and Article 6 on the right to life. The Committee recommended that "the provisions of the Civil and Penal Codes [of Peru] should be revised in the light of the obligations laid down in the Covenant."138 Nevertheless, no evidence has appeared that Peru has amended this inhuman treatment of women.

An instance that occurred on Germany's border with the Netherlands also demonstrates women's continuing liability to be subjected to inhuman and degrading treatment directly by governmental officers. ${ }^{139} \mathrm{~A}$ returning German woman was interrogated by German border guards, and subjected to physical examination to determine whether she had recently received an

134. Beijing Platform, supra note 9, II 135.

135. Cairo Programme, supra note 8, II 4.10.

136. Trial of Ulrich Greifelt and Others, 8 L. Reps of TrIals of War Crims. 1 (1949).

137. United Nations, Report of the Human Rights Committee, Doc. CCPR/C/79/Add.72 (1996), II 15.

138. Id. II 22.

139. Karlhans Liebl, Ermittlungsverfahren, Strafverfolgungs-und Sanktionspraxis beim Schwangerschaftsabbruch (The Practice of Criminal Prosecution and Punishment in the Case of Abortion) (1990). 
abortion in the Netherlands that would have been unlawful under German law due to her evasion of mandatory pre-abortion counseling requirements. This humiliating enforcement of administrative conditions shows the ease, oversight, and indifference with which women's human rights to be treated with dignity are disregarded where abortion is concerned.

Many women who are subjected to inhuman or degrading treatment and to discrimination on account of their race or ethnicity do not have access to redress through courts of law or human rights tribunals, and cannot obtain legal remedies for such human rights violations. However, media exposure of such abuses can lead to improved treatment. For example in Canada in 1992, the media exposed hospital practice in the Northwest Territories of denying anesthesia for pain relief to Inuit, Indian, Metis, and other women undergoing abortions. ${ }^{140}$ As a result of this exposure, the Minister of Health for the Northwest Territories established an independent review that resulted in changes in medical practice. ${ }^{141}$ Comparable to reactions to the cases above of violations of women's human rights to security and liberty of the person by courts in Ireland and Bolivia, this shows growing democratic distaste of inhumane abortion laws and practices.

\section{B. Non-discrimination and Due Respect for Difference}

The right to non-discrimination has evolved to require that we treat the same interests without discrimination, for example in ensuring that all people have access to basic health care. Non-discrimination also entails treating significantly different cases according to those differences. For example, the European Court of Human Rights explained in 2001 that it:

$[\mathrm{H}]$ as so far considered that the right under Article 14 [of the European Convention on Human Rights] not to be discriminated against in the enjoyment of the rights guaranteed under the Convention is violated when States treat differently persons in analogous situations without providing an objective and reasonable justification ... However, the Court considers that this is not the only facet of the prohibition of discrimination in Article 14. The right not to be discriminated against ... is also violated when States without an objective and reasonable justification fail to treat differently persons whose situations are significantly different. ${ }^{142}$

140. Miro Cernetig, NWT Orders Abortion Inquiry: Hospital Used No Anaesthetics, Globe \& Mall (Toronto), 2 Apr. 1992.

141. No Choice: Canadian Women Tell Their Stories of lllegal Abortion (Childbirth by Choice Trust ed., 1998).

142. Thlimmenos v. Greece (2001) 31 E.H.R.R. 15, II 44. 
Women are often discriminated against in the exercise of their reproductive rights because governments, without an objective and reasonable justification, fail to treat women according to their different reproductive function. Sex discrimination is often compounded by discrimination, on such grounds of race and ethnicity, age, health status, and disability.

\section{Sexual Non-Discrimination}

\section{a. CEDAW General Recommendation 24: Women and Health}

States Parties to the Women's Convention accept the obligation to confront women's inequality by addressing "all forms" of discrimination that women suffer, including discrimination on grounds both of sex, which is a biological characteristic, and of gender, which is a social, cultural, and psychological construct. The Women's Convention directs primary attention to women's health and well-being through Article 12. By this Article, member states agree to "take all appropriate measures to eliminate discrimination against women in the field of health care in order to ensure, on a basis of equality of men and women, access to health care services, including those related to family planning." ${ }^{143}$

In 1999, CEDAW elaborated the content and meaning of this Article in its General Recommendation 24: Women and Health. ${ }^{144}$ The Recommendation requires that states, when they periodically report under the Women's Convention, address distinctive features of health and life that differ between women and men, taking into account such factors as:

- biological factors including differing reproductive health needs and functions,

- socio-economic factors including unequal power relations,

- psychosocial factors such as postpartum depression, and

- health system factors such as the protection of confidentiality, especially for the treatment of stigmatizing conditions such as unwanted pregnancy and HIV/AIDS. ${ }^{145}$

General Recommendation 24 explains that the legal obligation of States Parties is to provide information in their periodic reports on the impact of health policies and laws on women in contrast to the impact on men. ${ }^{146}$ This is reinforced by the Human Rights Committee, acting under the Political

143. Women's Convention, supra note 14, art. 12.

144. UN GAOR, 1999, UN Doc. A/54/38/Rev. 1, 3-7.

145. CEDAW, supra note 15, Gen. Rec. 24, II 12.

146. CEDAW, id., Gen. Rec. 24, II 19. 
Covenant, which specified through its General Comment on Equality between Men and Women that states are now required to provide data on "pregnancy and childbirth-related deaths of women." ${ }^{147}$ Governments must accordingly report on the mortality and morbidity resulting from pregnancy and childbirth, and unsafe abortion, and mortality and morbidity rates and causes among men in the same age-groups.

The General Recommendation explains states' obligations to respect, protect, and fulfill women's rights to health care. The obligation to respect rights requires the removal of barriers to access to care, including "laws that criminalize medical procedures only needed by women and that punish women who undergo these procedures."148 Laws criminalizing medical procedures to which only women have resort would by definition include criminal abortion laws.

The obligation to protect rights relating to women's health

$[R]$ equires States parties, their agents and officials to take action to prevent and impose sanctions for violations of rights by private persons and organizations ... [including] [t]he enactment and effective enforcement of laws and the formulation of policies, including health care protocols and hospital procedures to address violence against women and abuse of girl children and the provision of appropriate health services. ${ }^{149}$

Where states rely on private clinics to provide legal abortion services, they are obligated to ensure that services are reasonably available, and are delivered in ways that are respectful of women's rights concerning dignity.

General Recommendation 24 further explains that the duty to fulfill rights places an obligation on states to: "take appropriate legislative, judicial, administrative, budgetary, economic and other measures to the maximum extent of their available resources to ensure that women realize their right to health care." ${ }^{\prime 150}$

For instance, where studies show high rates of maternal mortality and morbidity, they put governments on notice that they might be in breach "of their duties to ensure women's access to health care."151

\section{b. National Jurisprudence}

Consistently with General Recommendation 24, national courts are beginning to recognize that denial of safe abortion services constitutes sex

147. Hum. Rts. Comm., Gen. Comm. 28: Equality of Rights between Men and Women, adopted 10 Oct. 2000, UN GAOR 2000, UN Doc. A/55/40, Annex VI, at 153, II 10.

148. CEDAW, supra note 15, Gen. Rec. 24, II 14.

149. Id. II 15.

150. Id. II 17.

151. Id. 
discrimination. In conditions of therapeutic need, men are not exposed to legal denial of, and criminal punishment for resort to, safe medical services, while women often face legal and practical obstacles in seeking therapeutic abortion. For example in the United States, the Supreme Court of New Mexico held in 1999 that:

New Mexico's Equal Rights Amendment requires a searching judicial inquiry to determine whether the [Human Services] Department's rule prohibiting state funding for certain medically necessary abortions denies Medicaid-eligible women equality under law. We conclude from this inquiry that the Department's rule violates New Mexico's Equal Rights Amendment because it results in a program that does not apply the same standard of medical necessity to both men and women, and there is no compelling justification for treating men and women differently with respect to their medical needs in this instance. ${ }^{152}$

The rule in question, Rule 776, defines abortion as "medically necessary" when a pregnancy aggravates a pre-existing condition, makes treatment of a condition impossible, interferes with or hampers a diagnosis, or has a profound negative impact upon the physical or mental health of an individual." 153

The New Mexico Constitution guarantees that "[e]quality of rights under the law shall not be denied on account of the sex of any person." ${ }^{154}$ The Court explained that the judges "view New Mexico's Equal Rights Amendment as the culmination of a series of state constitutional amendments that reflect an evolving concept of gender equality in this state," and concluded that

New Mexico's Equal Rights Amendment is a specific prohibition that provides a legal remedy for the invidious consequences of the gender-based discrimination that prevailed under the common law and civil law traditions that preceded it. As such, the Equal Rights Amendment requires a searching judicial inquiry concerning state laws that employ gender-based classifications. This inquiry must begin from the premise that such classifications are presumptively unconstitutional, and it is the State's burden to rebut this presumption. ${ }^{155}$

The Court further observed that "[u]nder federal law, the state's interest in the potential life of the unborn is never compelling enough to outweigh the interest in the life and health of the mother."156

152. New Mexico Right to Choose/NARAL v. William Johnson, Secretary of the New Mexico Human Services Department, 126 N.M. 788, 792 (1999).

153. Id. at 791 .

154. Const. of the State of New Mexico (adopted 21 Jan. 1911, as amended through 1975) at art. II, § 18.

155. New Mexico Right to Choose/NARAL, supra note 152, at 800.

156. Id. at 804 . 


\section{Racial and Ethnic Non-Discrimination}

In some countries, women of particular races and ethnic groups are often discriminated against in the exercise of their reproductive rights. ${ }^{157}$ The values at stake are reflected in the language of the Preamble to South Africa's Choice on Termination of Pregnancy Act 1997, through which the legislature stated the values that are intended to prevail. The first paragraph of the Act's Preamble states that its provisions are enacted "[r]ecognising the values of human dignity, the achievement of equality, security of the person, non-racialism and non-sexism, and the advancement of human rights and freedoms which underlie a democratic South Africa."158

The significance of this language is that the modern South Africa has been shaped in reaction to an explicit history of racial discrimination, ${ }^{159}$ but the country moved quickly to address discrimination on grounds of sex as well as on grounds of race.

South Africa's approach to abortion law reform reflects experience in many other countries, where it has long been recognized that socioeconomic elites and women associated with influential families in their communities have been immune from restrictive abortion laws, but that such laws have prejudiced the choice, health, and very lives of powerless women who are poor, young, and marginal to the societies in which they live. ${ }^{160}$

Women's experiences of race and ethnic discrimination are found in court cases, individual narratives, and scholarship. ${ }^{161}$ Evidence of discrimination is also found in reproductive health indicators, showing disparity in access to reproductive health services among different ethnic groups. Statistics on disparity in the risk of maternal death between majority and minority populations show up to ten times greater risk, for instance, in the aboriginal population as against the non-aboriginal population in Australia. ${ }^{162}$ Differences exist even where populations live in the same cities, such as in the United States, where the Afro-American population has a relative risk of maternal death 4.3 times higher than members of the non-black population. ${ }^{163}$ These contrasts often reflect racial and socio-economic

157. Dorothy Roberts, Killing the Black Body: Race, Reproduction, and the Meaning of Liberty (1997).

158. Choice on Termination of Pregnancy Act of 1997, Preamble (South Africa).

159. Jeremy Sarkin, Patriarchy and Discrimination in Apartheid South Africa's Abortion Laws, 4 Buffalo Hum. Rts. L. Rev. 141 (1998).

160. Alice Jenkins, Law for the Rich (1960).

161. See, e.g., Global Critical Race Feminism, supra note 59.

162. Hani K. Atrash, Sidney K. Alexander \& Cynthia J. Berg, Maternal Mortality in Developed Countries: Not Just a Concern of the Past, 86 Obstetrics \& Gynecology 700, 703 (October 1995).

163. Id. 
differences. A positive response to these differences compatible with human rights entitlements might be the allocation of reproductive health care resources proportionately to need, including family planning services backed up by abortion services for high risk pregnancies in the event of failure.

Both the International Convention on the Elimination of All Forms of Racial Discrimination (the Race Convention) and the Women's Convention require member states to take temporary special measures to accelerate de facto equality between men and women ${ }^{164}$ and to ensure adequate development and protection of certain racial groups. ${ }^{165}$ Some governments have claimed to meet their legal responsibilities to satisfy international human rights conventions with regard to abortion by enacting liberalizing laws. However, many have accommodated these rights only as negative rights, leaving proposed beneficiaries dependent on their own resources alone to pursue them. Governments often fail to allocate public resources to furnish necessary services through which abortion rights can be realized, or to require health care providers or facilities to make services available and accessible. They therefore create rights for people with financial means, but not for poor people. The role of the human rights monitoring committees, acting under the various human rights treaties, is to determine whether rights legally available in theory are equitably available in practice to members of marginalized racial groups.

The Committee on the Elimination of Racial Discrimination has developed General Recommendation 25: Gender Related Dimensions of Racial Discrimination in order to assist countries reporting under the Race Convention to address the compounding forms of race and gender discrimination. ${ }^{166}$ The Recommendation recognizes that

[R]acial discrimination does not always affect women and men equally or in the same way. There are circumstances in which racial discrimination only or primarily affects women, or affects women in a different way, or to a different degree than men. Such racial discrimination will often escape detection if there is no explicit recognition or acknowledgment of the different life experiences of women and men, in areas of both public and private life. ${ }^{167}$

In considering gender-related dimensions of racial discrimination, the Committee will give "particular consideration to: the form and manifestation of

164. Women's Convention, supra note 14, art. 4.

165. International Convention on the Elimination of All Forms of Racial Discrimination, adopted 21 Dec. 1965, 660 U.N.T.S. 195 (entered into force 4 Jan. 1969), reprinted in 5 I.L.M. 352, art. 2.2 (1966).

166. Committee on the Elimination of Racial Discrimination, (CERD) Gen. Rec. 25: Gender Related Dimensions of Racial Discrimination, UN GAOR, 2000, UN Doc. A/55/18, Annex V, at 152.

167. CERD 25, id. II 1. 
racial discrimination; the circumstances in which racial discrimination occurs; the consequences of racial discrimination; and the availability and accessibility of remedies and complaint mechanisms for racial discrimination." ${ }^{\prime 168}$

An example of racial discrimination is a public health service that is inadequate because it fails to ensure that subgroups of women, such as Black or Mediterranean women, are treated according to their medically significant genetic predisposition, such as to sickle cell anemia. Where women with the sickle cell trait face health risks associated with unwanted pregnancies and do not have reasonable access to medically indicated abortion services, ${ }^{169}$ the Committee might consider that the lack of reasonable access is a form of racial discrimination that a state must remedy.

It has been explained that a consequence of the excessive certification procedures of the former South African Abortion and Sterilization Act of 1975 was to confine access to lawful abortion to primarily socio-economically advantaged women. A 1997 study of that law conducted by the South African Institute of Race Relations noted that:

During the period of the Act's operation, only an average of 800-1200 women per year qualified for legal abortion. Well over $66 \%$ of such women were white and from an urban middle-class background-at a time when whites constituted $16 \%$ of the general population. On the other hand, upwards of 44,000 women a year, the preponderance of them black and poor, had recourse to "backstreet" abortion. Unofficial estimates put the number of illegal abortions much higher, at 120,000 per year or more. Illegal abortions performed under unhygienic conditions exacted an inevitable toll on health. Each year about 33,000 surgical procedures were performed to treat the residue of septic abortions. The mortality rate stood at $425 .{ }^{170}$

In light of the consequences of the excessive South African certification procedures for Black women, a human rights treaty monitoring committee could well be vigilant in monitoring other laws with excessively bureaucratic procedures.

The new 1997 South African Act makes termination of pregnancy accessible upon racially non-discriminatory grounds. A procedure is legal upon a woman's request up to twelve weeks of pregnancy; up to twenty weeks on physical and mental health grounds, on socioeconomic grounds, and in cases of rape or incest; and after twenty weeks if the woman's life is endangered, or there is a risk that the fetus is severely deformed. The Act enables registered midwives who have completed the prescribed training

168. CERD 25, id. II 5.

169. AbouZahr, supra note 52.

170. Charles Ngwena, The History and Transformation of Abortion Law in South Africa, 30 Acta Academica 32-68 at 8-9 (footnotes omitted) (1998). 
course to perform abortions up to twelve weeks (sec. 2(2)). The law does not require third party authorizations for married women or minors. Medical practitioners or registered midwives shall advise pregnant minors to consult with parents, friends, or guardians, but the Act makes clear that services for termination of pregnancy cannot be denied because a minor chooses not to consult parents, guardians, or friends (sec. 5(3)). The Act accordingly excludes discrimination on grounds of age.

\section{Age Non-Discrimination}

Discrimination on grounds of young age is comprehensively addressed through the Children's Convention, by which states agree to "strive to ensure that no child is deprived of his or her right of access to . . . health care services."171 Intellectually mature young women's vulnerability to age discrimination is deepened when abortion services, available to adults on their own decision, are available to them only on the condition of parental authorization. ${ }^{172}$

Mature adolescents suffer unjust discrimination when they are not able to obtain reproductive health counseling and services with the same confidentiality as adults. The Children's Convention requires that "States Parties shall respect the rights and duties of the parents and, when applicable, legal guardians, to provide direction to the child in the exercise of his or her rights in a manner consistent with the evolving capacities of the child." 173

Courts are increasingly rejecting interpretations of laws that, on grounds of minor age alone, deny competent adolescents reproductive health services without parental consent. When minors are intellectually mature or emancipated, many courts will recognize their equal rights with adults to health care, including preventive care, and to confidentiality. ${ }^{174} \mathrm{~A}$ sign of maturity in minors is their understanding of the need to protect their reproductive health, and their requesting contraceptive services when they are or are about to be sexually active. Denial of reproductive health care services for adolescents often sets the scene for unplanned pregnancy and abortion.

The Cairo Programme recognizes that the "reproductive health needs of adolescents as a group have been largely ignored to date by existing

171. Children's Convention, supra note 71, art. 24(1).

172. Corinne A.A. Packer, Preventing Adolescent Pregnancy: The Protection Offered by International Human Rights Law, 5 InT'L J. Children's Rts. 46 (1997).

173. Children's Convention, supra note 71, art. 14 (2).

174. Gillick v. West Norfolk and Wisbech Area Health Authority [1986] AC 112 (House of Lords, England). 
reproductive health services." ${ }^{175}$ As a result, in many countries, high rates of adolescent unmarried pregnancy are epidemic, and in others appear endemic. ${ }^{176}$ For example, in its Concluding Comments on the Report submitted by the government of Saint Vincent and the Grenadines, CEDAW noted the "very high rate of pre-teen and teenage pregnancy" and recommended improved reproductive health services and information for this age group. ${ }^{177}$

The Cairo and Beijing texts call for the removal of regulatory and social barriers to reproductive health information and care for adolescents. ${ }^{178}$ They recommend that countries ensure that the programs and attitudes of health care providers do not restrict adolescents' access to appropriate services, ${ }^{179}$ and that programs protect and promote the rights of adolescents to reproductive health education, information, and care in order to reduce the number of adolescent pregnancies. ${ }^{180}$

\section{Non-Discrimination on Grounds of Health Status/Disability}

Human rights conventions prohibit discrimination not only on specified grounds such as sex and race, but also on unspecified grounds. Unspecified grounds have been interpreted to include impaired health status or disability, including asymptomatic HIV positivity. ${ }^{181}$ The stigma against women with HIV/AIDS is exacerbated when they become pregnant, but is not to be a reason to deny or obstruct rights to otherwise indicated health care.

A serious denial of the right to non-discrimination on grounds of health status occurs when women are forced to terminate pregnancies they prefer to continue. For instance, compromise of the immune system that HIVpositive women suffer is further aggravated by pregnancy, which itself reduces women's immune reaction. It is reported that some hospitals in the United States have therefore urged HIV-positive pregnant women to terminate pregnancies, and that they have done so directively. ${ }^{182}$ They have,

175. Cairo Programme, supra note 8, II 7.41.

176. P. Senanayake \& M. Ladjali, Adolescent Health: Changing Needs, 46 INT'L J. Grnecologr \& OBstetrics 137 (1994).

177. Report of the Committee on the Elimination of Discrimination Against Women (CEDAW), Saint Vincent and the Grenadines, 16th Sess., U.N. Doc. A/52/38/Rev.1, II II 123-50, at II 147 (1997).

178. Cairo Programme, supra note 8, II 7.45; Beijing Platform, supra note 9, III 106-08, 281.

179. Cairo Programme, supra note 8, II 7.45; Beijing Platform, supra note 9, III 106-08.

180. Cairo Programme, supra note 8, II 7.46; Beijing Platform, supra note 9, IIII 83(k)(l), $107(\mathrm{~g}), 281$.

181. Bragdon v. Abbott, 524 U.S. 624 (1998).

182. Taunya L. Banks, Legal Challenges: State Intervention, Reproduction and HIV-Infected Women, in HIV, AIDS and Child Bearing: Public Policy and Private Lives 143-77 (Ruth R. Faden \& Nancy E. Kass eds., 1996). 
for instance, overstated risks of vertical (mother-to-child) transmission of HIV infection to children born of HIV-positive mothers, and been intolerant of requests by such mothers to continue their pregnancies. ${ }^{183}$ The risks to women's liberty and security that they will be pressured to terminate pregnancies provide the threat of a human rights violation in otherwise liberating national proposals that restrictive abortion legislation be amended to allow medical termination of pregnancy on the indication of a pregnant woman's HIV-positive status. ${ }^{184}$

\section{Citizenship}

\section{Women as Equal Citizens}

Discrimination excludes those who are subjected to it from equality with others who are not, particularly the perpetrators of discrimination. That is, discrimination is an exercise in superiority. The abortion-related discrimination that women suffer on grounds of sex and gender, often coupled with discrimination on grounds of race, ethnicity, and, for instance, age, illustrates the pervasive violation of the right to equality that creates the subordinate status that many women occupy in their families, communities, wider societies, and legal systems. The burdens of pregnancy, post-partum recovery, nursing, and care of a dependent child or children for years, deny a woman other opportunities for applications of her energy, time, and talents that she may justly forgo only voluntarily.

The power that a state claims to conscript women to give their bodies against their will to deliver children at its legal demand confirms that women are only lesser or second-class citizens. Since the end of legal feudalism and slavery, men are not forced by law to render bodily service and sacrifice at the will of social superiors, and military conscription in war almost invariably allows rights of conscientious objection. Under restrictive criminal laws, women who conscientiously object to involuntary continuation of pregnancy by termination become criminals, liable to forfeit many of the freedoms that remain to them.

Women's lack of equality and bodily integrity under laws that deny them reproductive self-determination is increasingly perceived as a violation not only of human equality, but of full citizenship. Citizens in democracies are full participants in making the laws by which they

183. Mukdawan Sakboon, Pregnant HIV Victims Denied Every Option by Hospital, Nation (Bangkok), 31 July 1997.

184. Temsak Trisophon, Abortion Law Faces Key Change, Bangkok Post, 3 Oct. 1998. 
voluntarily abide, whose will can become law. Restrictive laws on abortion are products of times, many of which continue, when women lacked or lack the political power of full citizenship to overcome patriarchal governments. Such governments are often reliant on the support of authoritarian religious institutions whose leaders exercise spiritual autocracy and command obedience. The governments and religious institutions that support restrictive abortion laws include few if any women, and some deliberately exclude them.

Issues of citizenship have arisen in debates in the US concerning whether the Supreme Court's abortion decision in Roe v. Wade is better justifiable and sustainable on the basis of the Court majority's reasoning on rights of privacy, or on rights of equality, ${ }^{185}$ or whether the reasoning centrally implicates both. ${ }^{186}$ Denial of reproductive rights, including to abortion, is increasingly seen as a denial of women's citizenship. This vision of citizenship as possession of equal power of participation is both geographically and legally expansive. For instance, in addressing constitutional rights in the Supreme Court of Canada, Chief Justice Dickson observed that:

The Court must be guided by the values and principles essential to a free and democratic society which I believe embody, to name but a few, respect for the inherent dignity of the human person, commitment to social justice and equality, accommodation of a wide variety of beliefs, respect for cultural and group identity, and faith in social and political institutions which enhance the participation of individuals and groups in society. ${ }^{187}$

In this spirit of enhancement of social participation or citizenship, the Chief Justice two years later led the Court's majority judgment holding the restrictive national criminal abortion law unconstitutional, invoking its denial of women's equal right with men to security of the person. ${ }^{188}$

Citizenship has more recently triggered wider political, philosophical, sociological, legal, and related analysis in Western Europe in the 1990s, particularly since the 1997 Maastricht treaty of the European Union established transnational European citizenship. ${ }^{189}$ Constructions of citizenship generally and women's citizenship particularly vary according to the social, political, and legal context of a country.

185. Anita L. Allen, The Proposed Equal Protection Fix for Abortion Law: Reflections on Citizenship, Gender, and the Constitution, 18 Harv. J. L. \& PuB. Pol. 419 (1994-95).

186. Reva Siegel, Reasoning from the Body: A Historical Perspective on Abortion Regulation and Questions of Equal Protection, 44 Stanford L. Rev. 261 (1992).

187. R. v. Oakes, [1986] 1 S.C.R. 103, at 136.

188. R. v. Morgentaler v. The Queen 44 D.L.R.(4th) 385, at 402 (1998).

189. Sujit Choudhry, Citizenship and Federations: Some Preliminary Reflections; The Federal Vision: Legitimacy and Levels of Governance in the US and the EU, in THE US AND THE EU 377-402 (Kalypso Nicolaidis \& Robert Howes eds., 2001). 
In Latin America, for example, there are at least two dynamics in the construction of women's citizenship. One is the dynamic of ensuring that women have the same rights and duties as men with regard to citizenship, such as in their ability to vote and pass on citizenship to their children. The other is women's ability to engage in social and political movements to determine their destinies. ${ }^{190}$ Feminist movements mobilizing against dictatorship and abuse of authority have been particularly strong in Latin America, and have facilitated movements through which women have translated survival strategies into political and legal demands for access to services, including reproductive health services. ${ }^{191}$ The women's movement ties reproductive freedom into the struggle to ensure that women are subjects of the state, not objects, and engines, rather than clients, of development. ${ }^{192}$ In this context, the right to abortion represents achievement of women's control of their destinies in society. The construction of citizenship cannot be reduced to a simple list of legal rights, but rather requires the vindication of a series of civil, political, social, economic, and cultural rights. Moreover, this view of citizenship includes a set of organizational practices that allow women to exercise their power in the public sphere. ${ }^{193}$

The effectiveness of women's policy agencies in assisting women's movements in achieving their procedural and substantive policy goals is described as state feminism. ${ }^{194}$ Effectiveness will depend on a variety of variables, including the strength of the women's movement, the activities and characteristics of women's policy agencies, characteristics of the communal women's movement, and the policy environment. ${ }^{195}$ The legal status of women's rights to safe abortion is often a measure or barometer of the effectiveness of state feminism and respect for women's citizenship, in that abortion is safest where women are more respected as citizens of the countries in which they live.

190. Jane Jacquette, The Women's Movement in Latin America (1989).

191. Berengere Marques-Pereira, Los Derechos Reproductivos como Derechos Ciudadanos (Reproductive Rights and Citizenship Rights), in La Ciudadania a Debate (Citizenship Debated) 126 (Eugenia Hola \& Ana Maria Portugal eds., 1997); Leyla de Andrade Linhares Barsted, Ten Years of Struggle to Legalize Abortion in Brazil, in Women WatCHED and Punished 223-247 (R. Vasquez ed., 1993).

192. Magdalena Leon, Mujeres, Genero and Desarrollo (Women, Gender and Development), in Estudos Basicos de Derechos Humanos IV (Laura Guzman \& Gildo Pacheco eds., 1997).

193. Marques-Pereira, supra note 191, at 126; M. Barquet, Derechos Reproductivos: Muher y Socied (Reproductive Rights: Women and Society), 1992.

194. Dorothy M. Stetson, Conclusion: Comparative Abortion Politics and the Case for State Feminism, in Abortion Poltics, Women's Movements and the Democratic States: A Comparative Study of State Feminism 267-95 (Dorothy M. Stetson ed., 2001).

195. Id. 


\section{Women's Speech}

It is trite to observe that knowledge is power. Citizens' power to participate as they wish in the activities of their families and societies significantly depends on their access to information. ${ }^{196}$ The United Nations Development Programme recognizes that there is an interdependency between enjoying political freedom and participation, enjoying a decent standard of living, and being knowledgeable and enjoying good health. ${ }^{197}$ Thus, a full understanding of the concept of citizenship mandates a recognition of the importance of access to health information in the well-being of the citizen. In many cases, however, women have been deprived of the full benefits of citizenship with respect to information about health care procedures. ${ }^{198}$ Ultimately, this builds a self-renewing cycle that continues to marginalize women's roles and rights as citizens.

Regarding reproductive health and self-determination, the Women's Convention requires that women have "specific educational information to help to ensure the health and well-being of families, including information and advice on family planning." 199 Both the Cairo Programme and the Beijing Platform require governments to remove legal, medical, clinical, and regulatory barriers to reproductive health information ${ }^{200}$ and to improve its quality. ${ }^{201}$

In a number of countries, however, it is a criminal offense, sometimes still described as a crime against morality, to spread information of contraceptive methods. In countries with restrictive abortion laws, it may be an offense to publicize access to other countries where women can obtain pregnancy termination services on more accommodating grounds. ${ }^{202}$ In 1989, for instance, the Supreme Court of Ireland upheld injunctions prohibiting Irish student unions from distributing information of abortion clinics offering lawful services in Britain. ${ }^{203}$ In 1992, the European Court of Human Rights found these decisions to violate Ireland's international

196. Noel Whitty, The Mind, The Body, and Reproductive Health Information, 18 Hum. RTs. Q. 224 (1996); Lynn Freedman, Censorship and Manipulation of Reproductive Health Information, in The Right to Know: Human Rights and Access to Reproductive Health INFORMATION 1-37 (Sandra Coliver ed., 1995).

197. United Nations Development Programme, Human Development Report 200253 (2002).

198. Freedman, supra note 196, at 1-37.

199. Women's Convention, supra note 14, art. 10(h).

200. Cairo Programme, supra 8, II 7.20; Beijing Platform, supra note 9, III 103, 107 (e).

201. Cairo Programme, supra note 8, II 7.23; Beijing Platform, supra note 9, II 103.

202. The Right to KNow, supra note 196.

203. Attorney General (S.P.U.C.) v. Open Door Counseling Ltd. and Dublin Well Woman Centre Ltd. [1994], 2 IR 333 [1994], 1 ILRM 256 (Supreme Court). 
human rights commitments to allow freedom of expression. ${ }^{204}$ The European Court found that the restraint on expression had obstructed Irish clinics from offering abortion counseling, and created a risk to the health of women who, due to lack of proper counseling, were seeking abortions at a later stage in their pregnancy. Reflecting on some women's disadvantages, the Court noted that "the injunction may have had more adverse effects on women who were not sufficiently resourceful or had not the necessary level of education to have access to alternative sources of information." 205

There is growing public recognition of the injustices of the efforts of the Irish government to control information and access to services. Concerning access to services, for instance, a lower Irish court had prohibited parents of a fourteen-year-old girl pregnant by rape from taking her to Britain to receive legal abortion, ${ }^{206}$ which was reversed on appeal. ${ }^{207}$ This dissatisfaction led to an amendment of the Irish Constitution in 1992 recognizing freedom to travel ${ }^{208}$ and to receive information of abortion services lawfully available in another country. ${ }^{209}$ The Supreme Court of Ireland subsequently upheld the constitutionality of these amendments. ${ }^{210}$

Various decisions of human rights tribunals reflect indirectly on rights to give and receive information regarding reproductive health, including lawful abortion. For instance, the European Court of Human Rights found the United Kingdom in violation of freedom of expression when its legislation severely curtailed private expenditures on literature for circulation in election campaigns. ${ }^{211}$ The literature in the case outlined the views on abortion of three competing candidates. The Court favored freedom of expression, including freedom of political debate, over this governmental attempt to prevent election campaigns being unduly influenced by wellfunded interest groups.

In 1991, the US Supreme Court upheld a rule that prohibited health care providers in federally funded family planning clinics from counseling

204. Open Door Counseling Ltd and Dublin Well Women Centre Ltd v. Ireland, 15 Eur.Ct.H.R. 244 (1993).

205. Id. II 77.

206. The Attorney General v. X and Others [1992], ILRM 401.

207. The Attorney General v. $X$ and Others [1992], 1 IR 1 (Ir.S.C.).

208. Thirteenth Amendment of the Constitution Act, 23 Dec. 1992, Release 30, IRISH CURRENT Law Statutes Annotated 92 (Dec. 1992).

209. Fourteenth Amendment of the Constitution Act, 23 Dec. 1992, Release 30, IRISH CURRENT Law Statutes Annotated 92 (Dec. 1992).

210. Article 26 and The Regulation of Information (Services Outside the State for Termination of Pregnancy) Bill 1995, 1 IR 1 (Ireland) (1995).

211. Bowman v. United Kingdom, 141 Eur.Ct.H.R. at 1 (1996). According to this case, the freedom to travel (the Thirteenth Amendment) was upheld but was still held to be subordinated to the right to life of the unborn unless the travel for the purpose of obtaining an abortion was necessary to protect the life of the mother. 
patients by providing them with information on their lawful abortion options. ${ }^{212}$ In contrast, the same Court has precluded states from requiring that doctors show patients pictures of fetuses or explain fetal development graphically for the purpose of dissuading women from having abortions. ${ }^{213}$ Governmental manipulation of information, by denying or compelling its presentation to individuals at times when they are vulnerable and dependent, is a form of authoritarian denial of individual self-determination that is at the origin of the modern international human rights of individuals to decide what information to receive free of governmental control.

An issue arises, when women have not stated or clearly shown their refusal of abortion, ${ }^{214}$ whether they give adequately informed and free consent to medical management of particularly difficult or high-risk pregnancies when they have not been offered information of lawful options of abortion. The US Supreme Court has upheld national abortion "gag clauses" in health care providers' terms of employment or payment by government agencies. ${ }^{215}$ Such agencies may therefore prohibit health care providers from informing patients of constitutional rights to abortion available to them. ${ }^{216}$ However, litigation is pending claiming that the Global Gag Rule, as revived in January 2001, is unconstitutional. Overseas recipients of US funds must undertake not to contribute to abortion law liberalization in their own countries, and accordingly cannot engage with US-based nongovernmental organizations committed to world-wide abortion law reform for compliance with human rights standards. In denying staff members of US nongovernmental organizations rights to receive information and the power of discourse with overseas organizations, it is claimed that the Global Gag Rule violates their rights to receive information and free speech. The US Court of Appeals for the Second Circuit did not find this argument convincing. ${ }^{217}$

Laws that require the offer of pre-abortion counseling are consistent with women's rights to information, provided that the offer is an opportunity for enhanced exercise of choice. Laws that compel abortion applicants to

212. Rust v. Sullivan, 500 U.S. 173 (1991) at 4420.

213. City of Akron, Ohio v. Akron Center for Reproductive Health, 462 U.S. 416 (1983).

214. See Arndt v. Smith (1997), 148 D.L.R. (4th) 48 (Sup. Ct. Can.).

215. Rust, 500 U.S. at 214.

216. William J. Curran, et al., Health Care Law and Ethics 213-61 (5th ed., 1998).

217. Center for Reproductive Law and Policy v. Bush, US District Court, Southern District of New York, 2001 WL 868007 (S.D.N.Y.), 2001 (31 July 2001); 2001 U.S. Dist. LEXIS 10903, The Center for Reproductive Law \& Policy, Janet Benshoof, Anika Rahman, Katherine Hall Martinez, Julie Ernst, Laura Katzive, Melissa Upreti and Christina Zampas, Plaintiffs, v. George W. Bush, in his official capacity as President of the United States, Colin Powell, in his official capacity as Secretary of State, and Andrew Natsios, in his official capacity as Administrator of the United States Agency for International Development, Defendants, 01 Civ. 4986 (LAP), U.S. Dist. Ct. S.D.N.Y., 31 July 2001, Decided; 31 July 2001, filed. 
listen to counseling they do not request or approve demean women as competent decision-makers, and violate their rights of liberty ${ }^{218}$ even when, as is not invariably the case, the counseling is non-judgmental. Legislation sometimes also requires that there be a "reflection delay" between a woman's request for lawful abortion and its performance, so that she may reflect on the moral and associated implications of her decision. These provisions also demean women as capable decision-makers, and are often applied to discourage or frustrate their choice.

\section{Women's Choice: Third Party Authorization Requirements}

The Cairo Programme and the Beijing Platform invoke individuals' right to private life to resist public officers' intrusions, in order to ensure that women can exercise self-determination and confidential choice in reproductive matters. ${ }^{219}$ CEDAW General Recommendation 24 explains that:

The obligation to respect rights requires States parties to refrain from obstructing action taken by women in pursuit of their health goals. . . For example, States parties should not restrict women's access to health services or the clinics that provide those services on the ground that women do not have the authorization of husbands, partners, parents or health authorities, because they are unmarried or because they are women. ${ }^{220}$

Laws or practices that require third party authorization of women's abortion, for instance by their male partners, parents, doctors, or hospital committees, have been scrutinized for their negative impact on health and their infringement of women's rights to make decisions in their private lives. Claims by women to choice of lawful abortion over their partners' attempted vetoes have been consistently upheld by courts in countries of many regions of the world, ${ }^{221}$ the European Court of Human Rights, ${ }^{222}$ and the Commission of Human Rights. ${ }^{223}$

218. Nanette Funk, Abortion Counseling and the 1995 German Abortion Law, 12 ConN. J. of INT'L L. 33 (1996).

219. Cairo Programme, supra note 8, IIII 7.3, 7.12, 7.17-7.20; Beijing Platform, supra note 12, III 103, 107(e), 108(m), 267.

220. CEDAW Gen. Rec. 24, supra note 15, II 14.

221. A v. B, 35 (iii) P.D. 57 (Supreme Court of Israel, 1981); Attorney-General (QLD) ex rel. Kerr v. T, 46 ALR 275 (High Court of Australia, 1983); C. v. S., 2 W.L.R. 1108 (Court of Appeal, England, 1987): Judgment of 15 Feb. 1978, Dec. No. 157/77, 3 Yugoslav Law 65 (Constitutional Court of Yugoslavia, 1979); Judgment of 31 Oct. 1980, Conseil d'Etat, D.S. Jur. 19,732 (Council of State of France, 1980); Kelly v. Kelly, 2 FLR 828 (Court of Session Scotland 1997); Planned Parenthood v. Danforth, 428 U.S. 52, 69 (1976); Tremblay v. Daigle, (1998) 62 D.L.R. (4th) 634, 665 (Can.).

222. H v Norway, 73 Decisions and Reports 155 (1992) (European Court of Human Rights).

223. Paton v. United Kingdom, 3 E.H.R.R. 408 (1980) (Eur. Comm'n Hum. Rts.). 
Courts have uniformly rejected claims that abortions requested by women that are otherwise lawful are unlawful without authorization of male partners. The Italian Constitutional Court, for instance, rejected a claim that Italy's abortion law was in violation of Articles 29 of the Constitution because it provided no role for the husband in a wife's determination whether to have an abortion. ${ }^{224}$ Article 29 states that marriage is based on the moral and legal equality of a husband and wife. The Court held that the legislature had placed the burden of making an abortion decision on the wife, and that this decision was rational in light of the much greater effect that pregnancy has on a woman's physical and mental health than on those of a man. The European Court of Human Rights consistently reasoned that any interpretation of a putative father's right must first take into account the rights of the woman requesting abortion, since she is the person primarily concerned with the pregnancy and its termination or continuation. ${ }^{225}$

The US Supreme Court has considered a law enacted in Pennsylvania that requires a married woman not necessarily to obtain her husband's authorization, but to sign a statement that she had notified him of her intent to obtain an abortion. ${ }^{226}$ The Court held such a provision unconstitutional as a violation of the woman's right to privacy. However, the Court upheld provisions that require the woman to receive certain information at least twenty-four hours before the abortion is performed, that mandate the informed consent of one parent of a minor seeking an abortion, and place reporting requirements on facilities providing abortion services.

\section{Conscience and Professional Duty}

Some hospitals and other health care facilities make an institutional claim to allegiance to a religious faith that condemns abortion, and to rights not to offer such procedures. The origin of human rights shows them to reside, however, only in individuals, not institutions such as legal corporations. Administrators of religiously affiliated facilities may claim the right not to become personally complicit in conduct they consider sinful. Their consciences should be accommodated to a maximum degree possible. However, when their facilities are publicly responsible for the health care of individuals of varied religious conscience, who have no access to alternative facilities, a conflict exists between the human rights of facility

224. Judgment No. 389 of 31 Mar. 1988, Corte Cost., Gazz. Ufficiale, 1 serie speciale, 13 April 1988, n.15 Giur. Cost e Civ. 2110 (1988).

225. H v Norway, supra note 222, at 170 .

226. Planned Parenthood of Southeastern Pennsylvania v. Casey, 505 U.S. 833 (1992). 
administrators and those whose health care and well-being are entrusted to them. Some countries have explicitly legislated that publicly funded health care facilities are required to satisfy requests for lawful health services made by members of the communities the facilities serve..$^{227}$

Health service providers' human rights entitle them, particularly on grounds of freedom of religion, to claim conscientious objection to their performance of abortion. Accordingly, they cannot be subject to legally enforceable demands that they participate. Health care providers may also claim rights of conscientious objection to lesser forms of collaboration in abortion procedures, such as nursing preparation of abortion patients. Women who are not at imminent risk of death cannot demand physicians' and other health care providers' participation in the direct performance of abortion procedures. They can, however, require health care facilities to have appropriate staff available to render the lawful abortion and related services they require unless, as in several of the United States, facilities have received legislated immunities.

Several countries' legislation makes explicit what is usually implicit in laws governing the general delivery of health care services, namely that they accommodate the right of conscientious objection. ${ }^{228}$ Section 4 of British Abortion Act 1967, as amended, serves as a model. Subsection 1 provides that "no person shall be under any duty, whether by contract or by any statutory or other legal requirement, to participate in any treatment . . . to which he has a conscientious objection." The burden of proof of objection rests on the person claiming it. The subsection does not affect the duty to participate in treatment necessary "to save the life or to prevent grave permanent injury to the physical or mental health of a pregnant woman." 229 In 1989, Denmark amended its abortion law to recognize rights of conscientious objection for health service providers and trainees, ${ }^{230}$ but requires facilities to ensure women's appropriate access to services. Similarly, legislation in Guyana, for instance, reflects the general background law governing health service providers, in that it recognizes conscientious objection in principle but it precludes such objection where women's lives are at risk and no alternative services are immediately available..$^{231}$

Conscience based on religious faith usually allows life-preserving interventions, including those that terminate pregnancies, under the doctrine

227. See, e.g., Danish Act on Abortion, Order 633 (15 Sept. 1986).

228. Emily N. Marcus, Conscientious Objection as an Emerging Human Right, 38 VA J. INT'L L. 507 (1998).

229. British Abortion Act 1967, as amended, § 4(2).

230. See supra note 227; Danish Acts. No. 350 (24 May 1989), 389 (7 June 1989) amending the 1986 Act.

231. Medical Termination of Pregnancy Act, No. 7 (1995). 
of double effect. ${ }^{232}$ Termination, for instance, of ectopic or tubal pregnancy is not regarded as direct or deliberate abortion. The scope of rights of objection is governed by features of individual national laws. For instance, some disallow refusals to deliver post-operative care to abortion patients and to type referral letters for abortions. ${ }^{233}$ It is often the role of courts to balance various interests at stake in the performance of abortions. Institutions' refusal to employ staff members unless they share a common conviction, whether to object to abortions or to perform them in all circumstances, may violate human rights duties of non-discrimination in recruitment for employment on grounds of potential employees' religious or other convictions. Laws usually contain implicit provisions, which the Danish law makes explicit, that institutions responsible for health services in their region must meet their duties to make lawful abortion services available by employing adequate staff, while respecting individuals' rights of conscientious objection. Nevertheless, CEDAW has criticized countries that have allowed health care providers' conscientious objections to deny women's timely access to legal abortion services, for instance in Croatia ${ }^{234}$ and Southern Italy. ${ }^{235}$ States may be internationally accountable under human rights conventions for failing to ensure proper recruiting practices to serve women's health interests.

Women's human rights to liberty and to security of abortion choice are diminished when health care providers deliver services not only without respect for patients' confidentiality, but also judgmentally. Providers may, for instance, approach women as being immoral, or ignorant because they have an unplanned pregnancy. More harmful are punitive treatments of women that deny them physical pain-relief and psychological comfort during performance of abortion procedures, or that are accompanied by threats against future unplanned pregnancies, such as denial of health services. Not only are health care providers responsible for such unethical, punitive approaches and treatments, but governments are liable when they fail to take measures to discourage, discipline, and eliminate practices that deny patients' human rights. For example, professional and institutional licensing bodies that discharge functions delegated by governments can sanction health care professionals and facilities when they violate patients' human rights.

232. Daniel P. Sulmasy \& Edmund D. Pellegrino, The Rule of Double Effect: Clearing Up the Double Talk, 159 ArChives of Internal Med. 545 (1999).

233. Janaway v. Salford Health Authority, 3 All ER 1079 (1988) (House of Lords, England).

234. Report of the Committee on the Elimination of Discrimination against Women: Croatia (18th Sess. 1998), U.N. Doc. CEDAW/C/1998/I/L.1/Add.3. (1998) II 31, 35 (1998).

235. Report of the Committee on the Elimination of Discrimination against Women: Morocco (16th \& 17th Sess. 1997), U.N. Doc. A/52/38/Rev.1 III 353, 360. 


\section{A WAY FORWARD: HUMAN RIGHTS NEEDS ASSESSMENT}

Guidance on a country's legal compliance with human rights obligations to advance women's health regarding abortion can be based on an assessment of the scope, causes, and consequences of unsafe abortion at national or particular community levels. Assessment can employ available data sources, or be based on the collection of relevant new data. Assessment should identify codes of medical ethics, laws, including the language of enacted laws and decisions of courts, and policies of governments, health care facilities, and other influential agencies that facilitate or obstruct abortion services. A determination should be made of whether codes, laws, and policies that would facilitate access are actually implemented, and if they are not, of how they might be. Laws and policies that obstruct women's choice regarding their health generally and abortion specifically, and their access to services, should be identified, along with laws that facilitate and obstruct women's empowerment.

Assessment is needed of compliance with human rights at different levels, including clinical care, the operation of health systems, and the influence of underlying social, economic, and legal conditions. These levels are not necessarily distinct and often overlap. Failure to respect women's human rights at one level can cause or exacerbate failure at another level. Social science, epidemiological, and legal research can be drawn upon to conduct a human rights assessment of abortion services. In addition, Concluding Observations of human rights treaty monitoring committees and human rights fact-finding reports often indicate what more needs to be done to bring laws, policies and practices into compliance with human rights standards. Examples are explored below of information that a human rights needs assessment might include when addressing the three levels of clinical care, organization of health systems, and underlying social, economic, and legal conditions. ${ }^{236}$

\section{A. Clinical Care}

An approach to assessing respect for rights in clinical care is to examine treatment protocols for women seeking abortion services, or treatment for incomplete or spontaneous abortion. If such treatment protocols do not exist, inquiries should address whether steps are being taken to develop

236. Compare the work on developing a human rights impact assessment in the context of Hiv/AidS by Lawrence O. Gostin \& Zita Lazzarini, Human Rights and Public Health in the AIDS Pandemic ch. 3 (1997) 
them. Where protocols exist, assessments are needed to determine the extent to which they require respect for women's decisions and the extent to which they are used in training health care providers and whether they are actually followed in the delivery of services.

An assessment should examine the ways clinical care for abortion incorporates attention to underlying diseases or conditions specific to or more prevalent among certain subgroups of pregnant women, such as malaria, sickle cell trait, hepatitis, and HIV/AIDS. Steps taken to ensure that abortion services are provided to affected women should also ensure that these underlying conditions are treated and that affected women are referred for appropriate treatment. The reproductive health problems among such women should be addressed in a nondiscriminatory, constructive way. An assessment should also examine responses to social conditions with clinical manifestations, such as domestic violence resulting in unwanted pregnancy that leads to unsafe abortion.

Emphasis should be on efforts taken to reduce the stigma of unplanned pregnancy, and whether resort to abortion in the clinical care context includes respectful treatment of all women seeking services, irrespective of their reasons, circumstances, or socio-economic status. An assessment might seek data, including anecdotal data, of whether providers show respect for women's dignity, and are non-judgmental toward abortion clients. Health care providers should be trained in the importance of maintaining confidentiality, since breaches may be violations not only of service providers' professional ethical duties, but also of laws on patient confidentiality. ${ }^{237}$

Resort to care for perhaps life-endangering post-abortion complications is deterred where laws permit or even compel medical practitioners to report women they believe may have had unlawful abortions to police authorities. For instance, in Argentina in 1998, the Supreme Court of the Province of Santa Fé held that a gynecologist was entitled to breach professional confidentiality to inform authorities that a patient seeking treatment for abortion complications may have initiated the procedure unlawfully. ${ }^{238}$ This type of reporting to police authorities and its judicial endorsement raise profound concerns about observance of women's human rights.

Even where induced abortion is legally restricted, women's health requires competent treatment for incomplete and spontaneous abortion, of

237. Bernard M. Dickens \& Rebecca J. Cook, Law and Ethics in Conflict Over Confidentiality, 70 Int'L J. GrneCOlogy \& ObStetrics 385-91 (2000).

238. Case T. 148 PS. 357/428, Corte Suprema de la Provincia de Sante Fe, 2 Aug. 1998 (Supreme Court of the Province of Sante Fe, Argentina). 
whatever origin. Post-abortion care requires that when women suffer complications following unlawful procedures, they be treated with the care, courtesy, and compassion that health service providers are expected to apply as an aspect of their professionalism. Deliberate cruelty or indifference to suffering is no more tolerable in the case of unlawful abortion than when, for instance, surgeons treat the wounds of criminal fugitives or military opponents. ${ }^{239}$ An assessment should consider means by which professional standards in post-abortion care are monitored and maintained.

\section{B. Health Systems}

An assessment of the degree to which women's reproductive and wider human rights are respected throughout the health system might be approached through an examination of barriers to the availability of care and to laws, policies, and practices that deter women from seeking access to care. Where assessment at the clinical level indicates unacceptable rates of hospitalization due to unsafe abortion, the relevant ministry of health might be encouraged to evaluate how the government might respond and, for instance, better meet the need for preventive family planning services. In May 1998, for instance, the Committee on Economic, Social and Cultural Rights, monitoring the Economic Covenant, expressed its concern in its Concluding Observations on the Report of Poland that "family planning services are not provided in the public health care system so that women have no access to affordable contraception." The Committee also noted that "restrictions have recently been imposed on abortions that exclude economic and social grounds for performing legal abortions . . . because of this restriction, women in Poland are now resorting to unscrupulous abortionists and risking their health in doing so." 240

Examination is required of barriers to availability of abortion and abortion-related services. Barriers include lack of implementation of related laws and policies that are beneficial to women's health, due to legal prohibition or restriction of procedures or, for example, abuse of conscientious objection to participation in lawful services by health personnel. Attention should be given to low priority of lawful abortion services in health facilities, or in allocation of necessary budgetary resources. Lack of services being offered at times when it is convenient for women to attend for

239. British Medical Association, Medicine Betrayed: The Participation of Doctors in Human Rights Abuses (1992).

240. Report of the Committee on Economic, Social and Cultural Rights, U.N.Doc. E/C.12/ 1998/28, II 12, at 40-49. 
them, including lack of facilities to care for their young children while they receive counseling and treatment, should be explored.

Deterrents to access to services a health care system claims to provide include third party authorization, such as spousal authorization requirements; ${ }^{241}$ failure to treat adolescents according to their "evolving capacity" to exercise mature choice in abortion care; ${ }^{242}$ and payment or co-payment requirements, particularly for adolescent girls. CEDAW has condemned as discriminatory against women the laws and policies that condition women's access to lawful abortion services upon the authorization of other persons or groups of persons, such as therapeutic abortion committees; men encounter no such obstacles to obtain the medical care they request. Addressing the Report submitted by the government of Turkey, for instance, CEDAW considered that the legal requirement that a woman obtain the authorization of her husband in order to have an abortion violated her right under the Women's Convention to equality before the law. ${ }^{243}$

Assessments are needed at the health systems level, of the degree to which legal grounds for abortion are actually put into operation. Some jurisdictions, such as some states in Mexico, recognize legal abortion following rape, but provide little or no facilities through which women can avail themselves of lawful procedures. ${ }^{244}$ In one such state, governmental health care providers notoriously obstructed access of an adolescent rape victim to services to which she was legally entitled, forcing her to deliver a child. ${ }^{245}$ In contrast, a women's health advocacy group in Brazil has developed collaborative arrangements with the police to investigate rape complaints and provide timely access to abortion services in legally justifiable cases, where the evidence of sexual aggression is persuasive. ${ }^{246}$ Women's health advocacy groups, working together with the Brazilian Federation of Associations of Gynecologists and Obstetricians and the Brazilian Ministry of

241. Rebecca J. Cook, International Protection of Women's Reproductive Rights, 24 N.Y. Univ. J. Int'L L. \& Pol. 645, 697-98 (1992); Reed Boland, Population Policies, Human Rights, and Legal Change, 44 Aм. Univ. L. Rev. 1257, 1276-68 (April 1995).

242. Rebecca J. Cook \& Bernard M. Dickens, Recognizing Adolescents' "Evolving Capacities" to Exercise Choice in Reproductive Health Care, 70 Int'L J. Grnecology \& OBstetrics 13-21 (2000).

243. Report of the Committee on the Elimination of Discrimination against Women, Turkey, 16th Sess, Doc. A/52/38/Rev 1, III 151-206, at II 196 (1997).

244. Marie Claire Acosta, Overcoming the Discrimination of Women in Mexico: A Task for Sysiphus, in The (Un)Rule of Law and the Underprivileged in Latin America 160-80 (Juan Mendez, Guillermo O'Donnell, Paulo S. Pinheiro eds., 1999).

245. Grupo de Informacion en Reproduccion Elegida (GiRe), Paulina: In the Name of the Law (2000).

246. Jacqueline Pitanguay \& Luciana S. Garbayo, Relatorio do Seminario a Implementacao do Aborto Legal no Servico Publico de Saude (Report of a Seminar on the Implementation of Legal Abortion with the Public Health Service) (Rio de Janeiro, Brazil: Cicadania, Estudo, Pesquisa, Informacao e Acao, 1995). 
Health, developed a treatment protocol for rape victims that is now widely used to guide services in hospital emergency departments and to train health service providers. Assessments should note such collaborations.

Assessments should determine whether abortion laws and policies require excessive qualifications for health care providers to perform abortion services. Where excessive qualifications are required, so limiting the number of personnel able to provide services, options should be explored to determine whether governmental agencies might change such policies, or whether, for instance, a court declaration might clarify whether other appropriately trained personnel such as nurses are legally able to provide services. The Royal College of Nursing of the United Kingdom sought a judicial declaration leading to clarification that abortion may be conducted, under medical supervision, along extended lines of authority. Accordingly, nurses who assist, even instrumentally, in the management of abortion procedures, were ruled to be legally protected in the same way as the doctors in charge. ${ }^{247}$

Legislation may show how health systems can calibrate requirements for approval of abortion to levels of medical intervention, such as to simplify requirements for the more basic services. For instance, the Guyanan and South African abortion laws permit termination of pregnancy during the first trimester to be undertaken or supervised by a registered medical practitioner in, for instance, a doctor's office. However, despite widespread debate about enactment of Guyana's 1995 law, major hospitals in the country were found at its enactment to be unprepared to implement its provisions, lacking means to deliver clinical services and lacking regulations for pre- and postabortion counseling for women and their partners. ${ }^{248}$ This lack of ability to implement progressive laws is not unique. Research shows that women still find it necessary to resort to abortion by unskilled personnel for instance in India ${ }^{249}$ and Zambia ${ }^{250}$ even though their laws were liberalized in 1971 and 1972 respectively. The problem is particularly acute in India, where over 90 percent of abortions are done in illegal settings due to a combination of indirect rights infringements and the structure of the health care system. ${ }^{251}$

247. Royal College of Nursing of the United Kingdom v. Department of Health and Social Security, 1 All ER 545 (1981) (House of Lords, England).

248. Fred E. Nunes, \& Yvette M. Delph, Making Abortion Law Reform Work: Steps and Slips in Guyana, 9 Reproductive Health Matters 66-76 (1997).

249. Bela Ganatra, Unsafe Abortion in South and South East Asia, in Priorities and Needs in the Prevention of Unsafe Abortion and its Consequences: Report of an International Consultation (Iqbal Shah \& Ina Warriner eds., forthcoming 2002) (on file with author).

250. Winny Koster-Oyekan, Why Resort to Illegal Abortion in Zambia? Findings of a Community-Based Study in Western Province, 46 Soc. Scı. \& Med. 1303 (1998).

251. Vandana Tripathi, Applying a Human Rights Framework to the Provision of Abortion Care and Related Reproductive Health Services in India, 2 J. Health \& Pop. in Dev. Coun. 11 (1999). 
Accordingly, an assessment cannot presume that legal reform itself achieves health system reform.

\section{Social, Economic, and Legal Conditions}

Barriers to improving women's reproductive health including access to safe abortion services are often rooted in social, economic, cultural, and legal conditions that infringe upon women's human rights. A human rights needs assessment might reveal that social factors, including lack of literacy and of educational or employment opportunities, deny young women alternatives to early unwanted or repeated pregnancy and deny them economic and other means of access to contraception.

Women's vulnerability to sexual and other abuses, in and out of marriage, increases their exposure to unplanned pregnancy and unsafe abortion, and has been associated with further deterioration of their health, including mental health. ${ }^{252}$ Investigation should determine, for instance, whether laws adequately protect girls and women from sexual coercion and sexual abuse. Studies show that forced first intercourse is prevalent in many communities, affecting as many as 32 percent of girls and women. ${ }^{253}$ Laws that inadequately protect girls and women from coercion in sexual relations undermine women's independence and ability to protect themselves from unwanted pregnancies. Assessment should focus on whether laws and policies exist and are enforced that afford women effective defense against unwanted sexual relations, so that they can control the timing and number of their births.

Gender-sensitive social science and legal research can identify how underlying socio-legal conditions relate to the incidence of unwanted pregnancy and resort to unsafe abortion. For example, a study in Dar es Salaam, Tanzania showed that 432 of 455 hospitalized young women (about 95 percent) were admitted for abortion complications. These abortions were due to unwanted pregnancies resulting from the young women's relationships with older men, who acted as so-called "sugar daddies" and paid for their food in exchange for sex. ${ }^{254}$

Several comparative studies are available that provide information on

252. Leyla Gulcur, Evaluating the Role of Gender Inequalities and Rights Violations in Women's Mental Health, 5 HeAlth \& Hum. Rts. 47-66 (2000).

253. Lori Heise \& Ellsberg M. Gottemoeller, Ending Violence Against Women, 11 PopuLATION RePORTS, Series I, at 9-17 (1999).

254. Gottlieb S. Mpangile, Melkizedeck T. Leshabari, David J. Kihwele, Induced Abortion in Dar es Salaam, Tanzania: The Plight of Adolescents, in Abortion in the Developing World 387-403 (Axel I. Mundigo \& Cindy Indriso eds., 1999). 
women's status and opportunities under laws in various countries ${ }^{255}$ and regions. ${ }^{256}$ Legal research can show how laws advance or compromise women's interests in their personal, family, and public lives, with indirect effects on their reproductive health. Family law frequently expresses the basic cultural values of a community, such as rights to inheritance of property including land. Cultures resistant to women's equality with men have unselfconsciously perpetuated women's subordination and powerlessness as a "natural" condition of family life and social order so profoundly as often to render women's disadvantage invisible. Where women's subordination and powerlessness are perceived, they are considered not just a feature but a necessary condition of social order and stability. Family and social discipline are seen as dependent on men's authority to make decisions.

Laws that entrench women's inferior status to men and interfere with women's access to health services seriously jeopardize efforts to improve women's reproductive and wider health. These laws take a variety of forms, such as those that obstruct economic independence by impairing women's education, inheritance, employment, or acquisition of commercial loans or credit, but they all infringe on women's ability to make their own choices about their lives and health. ${ }^{257}$ Account should be taken of criminal, family, and other laws that condone, tolerate, or neglect violence against women, and, for instance, of inequitable family, education, and employment laws that deny adolescent and adult women alternatives in life to marriage, or that condition women's self-realization on marriage and motherhood. These include laws that require or allow pregnant girls' expulsion from school, and virginity tests for admission to educational or employment training institutions.

The compatibility of abortion laws and policies with human rights entitlements may be understood through factors specific to women's circumstances. A human rights needs assessment must address how women cope with unplanned pregnancy and resort to safe and unsafe abortion services, the health care systems on which they are dependent, and the social, economic, and legal conditions that affect their reproductive health and choices.

255. The Anti-Abortion Law in Poland: The Functioning, Social Effects, Attitudes and Behaviors (Wanda Nowicka ed., 2000).

256. See, e.g., Violeta Bermudez, la Regulacion Judica del Abortio en America latina Y el Caribe (1997); Center for Reproductive Law and Policy, and Demus, Estudio para la Defensa de los Derechos de la Mujer, Women of the World: Laws and Policies Affecting their Reproductive Lives-Latin America and the Caribbean (1997) and Progress Report (2000); Center for Reproductive Law and Policy and International. Federation of Women Lawyers-Kenya Chapter, Women of the World: Laws and Policies Affecting their Reproductive Lives: Anglophone Africa (1997) and Progress Report (2001).

257. Center for Reproductive Law and Policy, Reproductive Rights 2000—Moving Forward (2000). 